\title{
PSYCHOSEMANTIC APPROACH TO STUDYING GENDER ROLE ATTITUDES
}

\author{
Victor F. Petrenko, \\ Olga V. Mitina \\ Lomonosov Moscow State University \\ Moscow
}

\begin{abstract}
This article concerns studies devoted to the analysis of stereotypes of women's behavior using a method of plural identification. This method has developed within the general psychosemantic approach and allows to study not only well realized social and mental representations, but those deep and implicit, too. The article describes three experiments. All of them are cross-cultural. In the first and the second experiments attitudes of Russian and Azerbaijan respondents were compared. The third experiment is focused on comparing the feedback received from Russian and US samples. It has been shown that cultural influence is more important than gender influence when we deal with attitudes towards female behavior and life scenarios. That means that positions of men and women of the same culture have more in common than responses pf women or men from different cultures. The method permits to conduct cross-cultural researches into different (sub)cultures both in one country or in different countries.
\end{abstract}

Keywords: Psychosemantics, semantic space, gender, social representations, factor analysis.

Gender roles' attitudes are people's beliefs about the appropriate roles and obligations of women or men. Such beliefs have been of great interest in the world psychology over the last 40 years, which actually is a period when attitudes toward gender roles, and the actual roles of women and men, begin to change (Aivazova, 1998; Basow, 1992; Beere, 1990; Costanzo \& Oskamp, 1993; Gapova \& Usmanova, 2000; Kostikova, 2005; Klimenkova, 1996; Lott, 1994; Mitina, 1999; Schetilina, 2006; Voronina, 2001; Williams, 1987).

In different cultures, norms allowing women and men to behave in one way or another, to play certain roles in family and society (gender roles) are sufficiently different. Ideas of gender roles, acceptable in a certain culture, formed in representatives of other cultures, countries, eth- 
noses are known as gender stereotypes. To emphasize that the matter is how gender roles are perceived by representatives of the same culture (i.e. themselves), the term of gender auto-stereotypes is used.

Gender roles, stereotypes and auto-stereotypes along with social attitudes related with them are regulated at a deep mental level of public consciousness and even have an influence upon this level themselves (as the most deep, stretching back to the roots in the distant past, handed over from one generation to another, the most stable, least prone to changes in the development of society). This mental level is shaped in the long course of history of society and has a variety of aspects, such as historical, social, economic, cultural, religious, political. American researcher G. Hofstede (1991) believes that women's roles are one of the most important parameters that can measure social psychology, common to all the studied cultures.

In ethnic female roles and stereotypes deep mentality of an ethnos manifests itself most clearly. Therefore, study of female stereotypes is a powerful projective method to describe and to understand the deep nature of attitudes and stereotypes of a country, ethnos, culture, and thereby contribute to the solution of many cross-national and ethnic problems.

Study of gender roles and stereotypes (both of women and men) is a very popular issue (Levant et al., 2003). Special scales for investigating gender roles, attitudes and stereotypes are worked out (Olson et al., 2006; Mitina, 1999; Mitina \& Petrenko, 2000).

While men are generally more changeable, women tend to bear more conservative ethnic factors in themselves (Baiburin \& Kon, 1991). In ethnic stereotypes of women's behavior, deep mentality of its ethnos reveals itself to the fullest extent. Therefore, research of female stereotypes allows to describe and to understand deep nature of ethnic sets and attitudes, and, consequently, to find opportunities to settle many national problems. Now we don't discuss which approach to explaining differences and similarities between women and men is right: biological, psychological or social.

Very often this issue is examined from cross-cultural, comparative aspects. Studies have shown that in gender role attitudes the differences between men and women are expressed in a more clear way, but vary from country to country. For example, in all countries women have more egalitarian beliefs than men do. On the one hand, in North America these differences are not so considerable as in Russia, on the other 
hand, if compared with China, where the differences are insignificant, both men and women unanimously agree that social roles of women and men should be different (see McHugh \& Frieze, 1997; Mitina, Cuthbert, \& Nizovskikh, 2003). There are some periods manifesting trends when both women and men change their views (Spence \& Hahn, 1997; Loo \& Thorpe, 1998), also, there are some periods when changes level off (Bryant, 2003). Among the factors causing such changes are social, political and economical conditions.

The most frequent option is to adhere to a study of one of the scales designed to measure gender attitudes. The vast majority of these scales have been offered by the U.S. scientists. That is why the majority of crosscultural researches aim at the adaptation of a U.S. scale to another culture and to comparison of results obtained in this culture with the U.S. results (Levine \& West, 1979; Hinshaw \& Forbes, 1993; Chia, Allred, \& Jerzak, 1997; Beere, King, Beere, \& King, 1984; Kalin, Heusser, \& Edwards, 1982; Bhushan, 1981).

However, we have to note that, when conducting cross-cultural studies, one simultaneously needs an adequate understanding of actions or statements of representatives of different cultures. This imposes restrictions on using purely verbal questionnaires or even those describing types of behavior and requires a consideration of prevailing cultural attitudes, opinions, values and attitudes of everyday consciousness that are in constant interaction and interdependence with individual consciousnesses of this society. Psychosemantic methods have a great advantage here, if compared with traditional diagnostic scales.

Anthropologists and sociologists undeniably have taken the lead in the empirical study of the stereotypes relating to women. In comparison, psychology is interested in deeper layers of individual and public consciousness. Psychologists investigate the influence on female value orientation and prevalence of social stereotypes in people's evaluation of ability of women to perform this or that kind of work; family-household stereotypes of woman's behavior are studied, too (Basow, 1992; Deaux \& Lewis, 1984; Nieva \& Gutek, 1981). Methods of psychoanalysis are widely used to study the influence of a sexual factor on psychology of an individual. However, at the experimental level psychoanalysis deals with individual consciousness and a transition to the analysis of mass consciousness is very complicated. Psychosemantic methods allow for a deeper analysis of mass consciousness (Fransella \& Bannister, 1977; Petrenko, 1987; 2005). 
The task of psychosemantics includes reconstruction of a personal system of values through which a subject percepts the world, other people, himself or herself, as well as study of its genesis, structure and functioning (Petrenko, 2005; Petrenko \& Mitina, 2008). Psychosemantic models were originally applied to describe the inner world view of a single person, in individual psychotherapy; later they widely extended to researches into world views of a "generic" subject (public consciousness), in particular, to examination of social ideas and attitudes and behaviors connected with them, including stereotypes of gender behavior. Successful use of psychosemantic methods for studying gender stereotypes of behavior and related attitudes is due to their well-structured, colorful expressivity, ordinariness; they clearly change in the course of social development and transformation of social consciousness, and vary from one society to another.

The psychosemantical approach is based on the methodological principle of studing human personality through studying "partiality" of human consciousness. Human consciousness is polyphonic in the sense of a plurality of "selves" and is dialogical (Bakhtin, 1979; Bodalev, 1983; Kon, 1978; Stolin, 1979; 1983). A human act, both someone's own or performed by somebody else, is viewed from the position of a plurality of significant others, who are referred to as "interjects" in the psychoanalytic tradition, as role positions in the theory of personal constructs of G. Kelly (1955). An expert evaluation of positions of significant others is not contained in extended reflexive acts, but appears to occur in the forms of "experience": in the forms of guilt or a sense of accomplishment in relation to "significant others," in the form of self-esteem or selfdeprecation - in relation to the ideal "self", in the form of own sense of futility and neglect or of belonging and love in relation to humanity. Nevertheless, the cause of any dissatisfaction with oneself and following discrepancy of requirements of any interjects may be at least partially realized and identified as a task for seeking personal sense (in the words of A.N. Leontiev (1978)). The methods based on comparison of the qualities attributed to oneself or own ideals, have found wide application in social psychology and pathopsychology, they determine specific traits of identification and assess self-access and self-esteem.

But the disadvantage of these methods consists in the following. Personal qualities expressed by adjectives reflect clear-cut estimation, and socially determined desire or the absence of such a desire which is real- 
ized by those under investigation, has an influence on their behavior, which, in due turn, leads to the deliberate or unintentional falsification of results. Besides, a procedure of description of a person with a set of qualities ascribed to him (her) is essentially objective (Petrenko, 1987; 2005), because a person, as an object of description in terms of discrete indications, appears in the role of a self-identical and therefore invariable in time. Such a person does not have inner contradictions and, consequently, an inner potential of development.

Another form of description of a person (in contrast to the description of his / her qualities) is a description of acts he / she can do, possible behavior in the suggested circumstances, i.e. the description via acts. Sentences like "I would reconnoiter ${ }^{1}$ with him / her", "this guy will not lose a chance", or "this man simply burns with the desire to work", proverbs, humorous catch-phrases, or even a cliché "a person is respected by his / her collective" characterize a person via generalized norms of behavior.

Semantic differentials used to describe another person via his / her possible behavior under a set of circumstances suggested by a researcher, provides much more reliable information, because a person gives motives of his / her acts taking into account his / her attitudes and values (Petrenko, 1987). An initial set of acts must satisfy following requirements.

1. Acts should be typical enough for the compared cultures and natural for those social groups or populations, on the basis of which a culturecomparative research is carried out. While compiling a list of acts, a researcher should be "immersed" enough in the culture in question not to substitute real problems of the tested with his / her own "projections."

2. A description of situations and acts should be formulated in colloquial words characteristic of a social groups under research.

3. If possible, a set of acts should proportionally represent different spheres of reality under investigation. The reason is that if a certain aspect is more widely represented in the offered behavioral situations it will disproportionally raise the contribution to the similarity and difference of role positions which are evaluated.

While making a list of roles, a researcher has to take into consideration that these roles should be typical for a studied culture and recognized by a tested group. It is necessary to include various behavior pat-

1 Means when being in the war. 
terns (used for theoretical conjectures), reflexive role position "I myself." We also advise to include an image of typical representatives of a given culture not only at the given moment, but in time perspective (in the past and in the future), along with approved and non-approved roles, stereotyped and personally related roles.

The resulted psychosemantic methods are called "a method of plural identification" (Petrenko, 1987).

Research methods. The goal of our research was to conduct a comparative study of female behavior stereotypes in different cultures and gender groups using the method of plural identification.

Our task was to detect differences in estimations and in attitudes to various actions and behavior styles of women in the cultures under investigation, and to find a small number of latent stereotypes (basic factors) of female behavior in public consciousness which determine attitudes toward a large number of particular acts, "behavior styles." Moreover, we were interested in revealing the most important differences in views on an ideal and proper behavior. The list of situations was made according to the principles mentioned above.

\section{Experiment 1. Cross-cultural studies of female stereotypes of Russians and Azerbaijanis using the psychosemantic method of "plural identifications"}

The subjects:

Total: 80 females from 20 to 23 years old, unmarried, among them

40 students of the Philology Department of the Azerbaijan Teachers' Training Institute, who came from various parts of Azerbaijan,

40 students of the Philology Department of the Moscow State University, originally from different cities of the Russian Federation.

Time of the experiment: 1990. At that time, both Azerbaijan and the Russian Federation were the republics of the USSR. Nevertheless, cultural differences have always existed mainly due to ethnicity and everyday behavioral patterns related to it.

Procedure of the experiment. The subjects assessed the probability of 90 acts taken from everyday life according to a 6-grade scale (from 0 to 5) from the following role positions: 1) I myself, 2) my mother, 3) an ideal woman from my point of view, 4 ) an ideal from the social point of view (social ideal), 5) a typical woman, 6) a woman of 40 years ago, 7) a 
woman in 20 years, 8) a woman with failed private life, 9) a woman despised by me, 10) a Russian woman (for Azerbaijani subjects) / an Azerbaijani woman (for Russian subjects), 11) a Georgian woman, 12) an Estonian woman.

After the scaling procedure, subjects were asked to give a self-report and fill in an anonymous questionnaire, which included the following data: age, ethnicity, marital status and place of residence. The subjects were grouped according to their answers. The experiment was conducted in groups for 2 days and took 2 hours each day.

Data analysis. The results of individual subjects were placed in 2 data matrices separately for the Azerbaijani and Russian groups of subjects, and then normalized so that the maximum possible score was 100 (if all subjects from the group attributed 5 to this role position for the act), and the minimum 0 (if nobody attributed any points to this role position for the act). Table 1.1 represents a fragment of this matrix. The answers which are in columns named AZ refer to the Azerbaijani subjects, and those named RU refer to the Russian subjects.

The simplest form of processing the original data matrix is to compare the role positions by calculating the correlation coefficients of paired roles through scores attributed to these roles for each act, i.e. calculating the coefficients of pair correlation of vertical columns of the original data matrix.

The coefficients of correlations in comparing answers of Azerbaijani and Russian samples are presented in Table 1.2. The upper triangle above the diagonal contains the correlations between roles according to answers of the Azerbaijani subjects, and the low one the correlations between roles according answers of Russian subjects. We can notice that both samples have a high degree of correlation of the image I myself and the ideal ( $0.9 / 0.8)$ positions. The Azerbaijani subjects demonstrate a higher identification with the image of the mother (0.8), compared with a Russian young women (0.6). The Personal ideals of both groups of the subjects are significantly close to the corresponding social ideals $(0.9$ / 0.9). However, images of the social ideals are considerably different for the Russian and Azerbaijani samples. For example, if the Russians think that the social ideal position is highly correlated with the woman in 20 years position and gives an almost zero correlation with the woman of 40 years ago position, then the situation is quite opposite for the Azerbaijani respondents. In their view, the social ideal posi- 
tion is more like a woman of the past (0.8), than a woman of the future (0.2). This relation of "contradict temporal orientation" of the Azerbaijanis and Russians is preserved for the personal ideals, but to less extent. Thus, the personal ideal of Russians more correlates with the woman in 20 years (0.6), than with the woman of 40 years ago (0.2), the individual ideal of Azerbaijanis is more like the woman of 40 years ago (0.5) than the woman in 20 years (0.4).

Nevertheless, it is interesting to note that, regardless the opposite "temporal orientation" of individual ideals of the two samples, compared with the social ideal, the personal ideal of Russian women is a little shifted towards the traditional image of a woman and the individual ideal of Azerbaijani is shifted towards a woman of the future. Thus, concerning their individual ideals, the Russian and Azerbaijani samples seem to have a more similar position in comparison with the positions defined in terms of the cultural and national environment. There is a convergence of stereotypes for young representatives of different nations. Thus, the correlation coefficient of the my ideal role positions of the Russians and of Azerbaijanis was $r=0.5$. The image of a typical woman for the Russian sample is also closer to that of a woman of the future (0.7), and the image of a typical Azerbaijani woman from the point of view of the Azerbaijani women is closer to the image of a woman of 40 years ago (0.7). Interestingly enough, there exists a significant correlation between the image of a typical woman and the image of a woman with a failed personal life (0.5) obtained on the basis of the results demonstrated by the Russian subjects. We shall return to the discussion of this dependence below.

A centering effect expressed itself in terms of comparing the image of a woman of the same ethnicity (a typical woman "in our society") and the same of another ethnicity, which was caused by greater differentiation in consciousness in the zone of someone's own national autostereotypes and less discriminating power at the periphery of its culturological area. Thus, the image of a typical woman of the same culture is less similar to a typical woman of another ethnicity for both samples. But images of Azerbaijani and Georgian women are highly similar (0.9) in the consciousness of the Russian subjects, and as for the Azerbaijani respondents, Russian and Estonian women are similar (0.8). This remarkable effect may be universal with respect to any content area, which becomes the object of awareness rights, due to the greater differentiating power of 
consciousness in the areas adjacent to the personal sphere (my nationality, my profession, my personal life range, the range of my interests, etc.). For example, the study conducted by B.M. Velichkovsky on a completely different material described a similar effect of centering caused by the biased position of the observer: during making of schematic maps, a distance between points which the subject knew well was overestimated, while a distance between places rarely visited by the subject was underestimated (Velichkovsky, Blinnikova, \& Lapin, 1986). In the area adjacent to the "I myself" reference system, consciousness is more differentiated and one may say that the semantic space has a larger scale. We can paraphrase the famous dictum "Knowledge is power" to sound as: "Knowledge generates semantic space."

A more complex form of data analysis and at the same time its representation or explication is the construction of subjective semantic spaces that are operational counterparts for categorical structures of individual consciousness. Constructing semantic spaces based on the use of factor analysis that reduces the dimension of the original space of acts (in this case 90), which differentiated role positions, to a few generalized latent factors, consolidating similar acts into a single dimension. A similarity measure for individual acts is the similarity of ratings, which subjects attribute to various role positions. The extracted factors reflect a base for classifications, which consciously or unconsciously are used when the subjects compare these acts. In the geometric representation of data the extracted factors are presented as the axis of the $n$-dimensional semantic space, where the dimensionality of the space is defined by the number of independent factors. The role positions can be represented as points within this semantic space. Places of the role positions (I myself, my mother, an ideal woman in my view, a typical woman, etc.) are based on summing up of their factor scores according to each factor and can provide a representation of role positions as appropriate points inside the $n$-dimensional semantic space. Similarities and dissimilarities of the analyzed role positions will correlate with the Euclidean distance between the points corresponding to role positions within the semantic space and will be expressed by the formula:

$$
D_{j j}=\sqrt{\sum_{k=1}^{n}\left(x_{i k}-x_{j k}\right)^{2}}
$$


where $D_{i j}$ is a distance between the role positions $i$ and $j ; x_{i k}$ is a factor score of the role position $i$ on factor $k ; x_{j k}$ is a factor score of the role position $j$ to factor $k ; n$ is a number of extracted independent factors.

Table 1.1

Fragment group matrix of the answers

given by Azerbaijanis and Russians

\begin{tabular}{|c|c|c|c|c|c|c|c|c|c|}
\hline \multirow[b]{2}{*}{$\begin{array}{l}\text { ACTIONS, DEEDS, } \\
\text { SITUATIONS }\end{array}$} & \multicolumn{9}{|c|}{ ROLES } \\
\hline & 壳 & 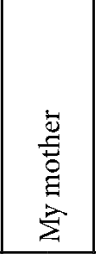 & 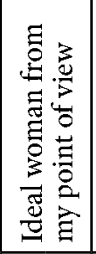 & 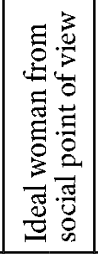 & 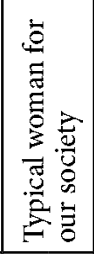 & 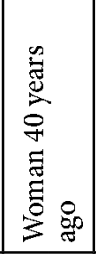 & 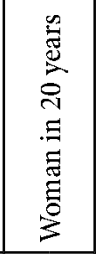 & 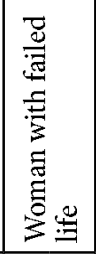 & 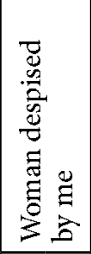 \\
\hline & AZ RU & AZ RU & AZ RU & AZ RU & AZ RU & AZ RU & AZ RU & AZ RU & $\mathrm{AZ} \mathrm{RU}$ \\
\hline $\begin{array}{l}\text { To meet a man } \\
\text { on the street, sup- } \\
\text { porting the talk } \\
\text { initiated by him }\end{array}$ & 1871 & $\begin{array}{ll}0 & 52\end{array}$ & $\begin{array}{ll}18 & 56\end{array}$ & 267 & $\begin{array}{ll}30 & 67\end{array}$ & $\begin{array}{ll}0 & 32\end{array}$ & 7276 & 6072 & $80 \quad 52$ \\
\hline $\begin{array}{l}\text { To send a marriage } \\
\text { announcement in } \\
\text { the paper }\end{array}$ & $\begin{array}{ll}0 & 20\end{array}$ & $\begin{array}{ll}0 & 5\end{array}$ & $\begin{array}{ll}8 & 13\end{array}$ & $\begin{array}{ll}0 & 33\end{array}$ & 1528 & $\begin{array}{ll}0 & 6\end{array}$ & $67 \quad 59$ & 6472 & 6064 \\
\hline $\begin{array}{l}\text { To feel the cons- } \\
\text { tant need for new } \\
\text { people }\end{array}$ & $\begin{array}{ll}82 & 67\end{array}$ & $\begin{array}{ll}71 & 32\end{array}$ & $\begin{array}{ll}81 & 68\end{array}$ & $\begin{array}{ll}70 & 74\end{array}$ & $\begin{array}{ll}58 & 79\end{array}$ & $\begin{array}{ll}50 & 48\end{array}$ & $90 \quad 75$ & 7656 & 4460 \\
\hline $\begin{array}{l}\text { To strive for uni- } \\
\text { versity education }\end{array}$ & $\begin{array}{ll}88 & 87\end{array}$ & $\begin{array}{ll}45 & 55\end{array}$ & $\begin{array}{ll}76 & 95\end{array}$ & $\begin{array}{ll}61 & 95\end{array}$ & $\begin{array}{ll}65 & 65\end{array}$ & $24 \quad 42$ & 10086 & 2878 & $24 \quad 42$ \\
\hline $\begin{array}{l}\text { To be unfaithful to } \\
\text { one's husband after } \\
\text { his unfaithfulness }\end{array}$ & $8 \quad 38$ & 114 & 1230 & $\begin{array}{ll}16 & 43\end{array}$ & 3256 & $\begin{array}{ll}0 & 29\end{array}$ & $55 \quad 55$ & 4855 & $\begin{array}{ll}72 & 83\end{array}$ \\
\hline $\begin{array}{l}\text { To tell one's col- } \\
\text { leagues about the } \\
\text { conflict with one's } \\
\text { husband }\end{array}$ & 45 & 1211 & 80 & $\begin{array}{ll}15 & 10\end{array}$ & $\begin{array}{ll}40 & 52\end{array}$ & $\begin{array}{ll}16 & 21\end{array}$ & $\begin{array}{ll}52 & 30\end{array}$ & 6164 & $\begin{array}{ll}71 & 82\end{array}$ \\
\hline $\begin{array}{l}\text { To do needlework } \\
\text { (sewing, embroi- } \\
\text { dery, knitting) for } \\
\text { family using }\end{array}$ & $\begin{array}{ll}63 & 80\end{array}$ & $\begin{array}{ll}80 & 91\end{array}$ & $\begin{array}{ll}91 & 92\end{array}$ & $\begin{array}{ll}80 & 96\end{array}$ & $\begin{array}{ll}67 & 80\end{array}$ & $84 \quad 72$ & $\begin{array}{ll}83 & 72\end{array}$ & $48 \quad 64$ & $\begin{array}{ll}28 & 32\end{array}$ \\
\hline
\end{tabular}




\begin{tabular}{|c|c|c|c|c|c|c|c|c|c|}
\hline $\begin{array}{l}\text { To make one's } \\
\text { husband remark in } \\
\text { the presence of his } \\
\text { friends }\end{array}$ & $\begin{array}{ll}0 & 44\end{array}$ & $\begin{array}{ll}8 & 46\end{array}$ & $\begin{array}{ll}0 & 33\end{array}$ & $13 \quad 31$ & $\begin{array}{ll}31 & 48\end{array}$ & $\begin{array}{ll}0 & 34\end{array}$ & $54 \quad 55$ & $\mid \begin{array}{ll}56 & 72\end{array}$ & $\begin{array}{ll}88 & 69\end{array}$ \\
\hline $\begin{array}{l}\text { To conceal from } \\
\text { one's husband, } \\
\text { having bought an } \\
\text { expensive purchase }\end{array}$ & $\begin{array}{ll}11 & 16\end{array}$ & $\begin{array}{ll}8 & 19\end{array}$ & $\begin{array}{ll}6 & 4\end{array}$ & $17 \quad 15$ & 3454 & 1032 & 2840 & 6064 & $\begin{array}{ll}81 & 82\end{array}$ \\
\hline $\begin{array}{l}\text { To endure nagging } \\
\text { mother in law } \\
\text { rather than "put it } \\
\text { in place" }\end{array}$ & $\mid \begin{array}{ll}72 & 33\end{array}$ & $88 \quad 56$ & $\begin{array}{ll}55 & 44\end{array}$ & 88 & 6751 & 9965 & $28 \quad 38$ & $\mid \begin{array}{ll}43 & 56\end{array}$ & $\begin{array}{ll}36 & 82\end{array}$ \\
\hline To smoke & $\begin{array}{ll}0 & 32\end{array}$ & $\begin{array}{ll}0 & 5\end{array}$ & $8 \quad 5$ & $0 \quad 54$ & 2668 & 08 & 5655 & $\begin{array}{ll}58 & 72\end{array}$ & 6484 \\
\hline $\begin{array}{l}\text { To participate in } \\
\text { public life actively }\end{array}$ & $48 \quad 60$ & 4368 & 6474 & 4470 & 5563 & 1645 & 8478 & $52 \quad 71$ & 2464 \\
\hline $\begin{array}{l}\text { To regard living } \\
\text { alone as better than } \\
\text { getting married }\end{array}$ & $\left|\begin{array}{ll}11 & 27\end{array}\right|$ & $\begin{array}{ll}0 & 27\end{array}$ & $\begin{array}{ll}0 & 24\end{array}$ & $\begin{array}{ll}0 & 32\end{array}$ & 1146 & $\begin{array}{ll}0 & 33\end{array}$ & 3644 & $\left|\begin{array}{ll}26 & 56\end{array}\right|$ & 4051 \\
\hline To go to disco clubs & $\begin{array}{ll}60 & 90\end{array}$ & 757 & $\begin{array}{ll}60 & 81\end{array}$ & 1698 & 4683 & 476 & 6095 & 5463 & 7676 \\
\hline $\begin{array}{l}\text { To think it is better } \\
\text { to divorce unloved } \\
\text { husband, than to } \\
\text { suffer for the sake } \\
\text { of one's children, to } \\
\text { whom he is atten- } \\
\text { tive and careful }\end{array}$ & $\left|\begin{array}{ll}31 & 59\end{array}\right|$ & $\begin{array}{ll}0 & 56\end{array}$ & $\begin{array}{ll}47 & 51\end{array}$ & $\begin{array}{ll}9 & 66\end{array}$ & 3664 & 436 & 6472 & 4352 & $\mid \begin{array}{ll}80 & 64\end{array}$ \\
\hline $\begin{array}{l}\text { To experience the } \\
\text { futility of one's life }\end{array}$ & $\begin{array}{ll}44 & 75\end{array}$ & $43 \quad 60$ & $\begin{array}{ll}6 & 50\end{array}$ & $4 \quad 44$ & $44 \quad 41$ & $\begin{array}{ll}50 & 30\end{array}$ & $48 \quad 64$ & $\begin{array}{ll}68 & 88\end{array}$ & $\begin{array}{ll}44 & 16\end{array}$ \\
\hline $\begin{array}{l}\text { To gossip with } \\
\text { neighbors }\end{array}$ & $16 \quad 52$ & 1236 & $\begin{array}{ll}10 & 26\end{array}$ & $20 \begin{array}{ll}20 & 46\end{array}$ & $\begin{array}{ll}48 & 79\end{array}$ & $44 \quad 68$ & $76 \quad 64$ & $62 \quad 64$ & $\begin{array}{ll}78 & 84\end{array}$ \\
\hline $\begin{array}{l}\text { To be hospitable } \\
\text { and welcoming } \\
\text { to friends of one's } \\
\text { husband, who are } \\
\text { not liked }\end{array}$ & $\begin{array}{ll}38 & 64\end{array}$ & $\begin{array}{ll}50 & 83\end{array}$ & 4184 & $\begin{array}{ll}68 & 72\end{array}$ & $\begin{array}{ll}50 & 60\end{array}$ & 6472 & $98 \quad 56$ & $\mid \begin{array}{ll}50 & 48\end{array}$ & $\mid \begin{array}{ll}20 & 21\end{array}$ \\
\hline $\begin{array}{l}\text { To run the family } \\
\text { budget }\end{array}$ & $\begin{array}{ll}38 & 79\end{array}$ & 3078 & 3266 & $32 \quad 76$ & 5188 & 1661 & 8084 & \begin{tabular}{|ll}
52 & 77
\end{tabular} & 6066 \\
\hline
\end{tabular}


Table 1.2

Inter-correlations between different roles for Azerbaijanis and Russians

\begin{tabular}{|c|c|c|c|c|c|c|c|c|c|c|c|c|}
\hline $\begin{array}{l}\text { WOMEN'S } \\
\text { ROLES }\end{array}$ & 岕 & 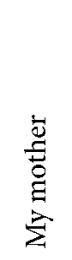 & 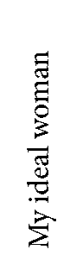 & 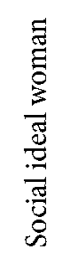 & 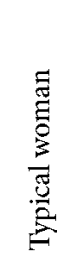 & 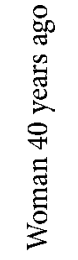 & 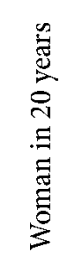 & 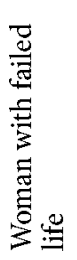 & 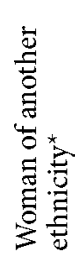 & 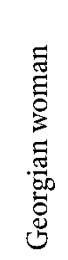 & 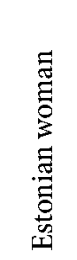 & 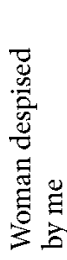 \\
\hline I myself & & 0.80 & 0.90 & 0.80 & 0.80 & 0.60 & 0.30 & 0.00 & -0.10 & 0.30 & 0.00 & -0.60 \\
\hline My mother & 0.60 & & 0.80 & 0.90 & 0.80 & 0.90 & -0.10 & 0.00 & -0.40 & 0.10 & -0.30 & -0.60 \\
\hline My ideal woman & 0.80 & 0.60 & & 0.90 & 0.80 & 0.50 & 0.40 & -0.10 & 0.00 & 0.30 & 0.00 & -0.60 \\
\hline $\begin{array}{l}\text { Social ideal } \\
\text { woman }\end{array}$ & 0.90 & 0.60 & 0.90 & & 0.90 & 0.80 & 0.00 & 0.00 & -0.30 & 0.10 & -0.30 & -0.70 \\
\hline Typical woman & 0.60 & 0.30 & 0.30 & 0.60 & & 0.70 & 0.10 & 0.00 & -0.20 & 0.20 & 0.20 & -0.50 \\
\hline $\begin{array}{l}\text { Woman } 40 \\
\text { years ago }\end{array}$ & 0.20 & 0.60 & 0.20 & 0.20 & 0.00 & & -0.30 & 0.00 & -0.50 & 0.00 & -0.50 & -0.50 \\
\hline $\begin{array}{l}\text { Woman in } 20 \\
\text { years }\end{array}$ & 0.70 & 0.10 & 0.60 & 0.70 & 0.70 & 0.30 & & 0.40 & 0.40 & 0.30 & 0.40 & -0.10 \\
\hline $\begin{array}{l}\text { Woman with } \\
\text { failed life }\end{array}$ & 0.30 & 0.20 & 0.20 & 0.30 & 0.50 & -0.10 & 0.40 & & 0.20 & 0.40 & 0.20 & 0.40 \\
\hline $\begin{array}{l}\text { Woman of an- } \\
\text { other ethnicity }\end{array}$ & 0.00 & 0.10 & 0.00 & 0.00 & 0.20 & 0.40 & -0.10 & 0.10 & & 0.60 & 0.80 & 0.40 \\
\hline $\begin{array}{l}\text { Georgian } \\
\text { woman }\end{array}$ & 0.00 & 0.20 & 0.00 & 0.00 & 0.10 & 0.50 & -0.10 & 0.10 & 0.90 & & 0.60 & 0.00 \\
\hline $\begin{array}{l}\text { Estonian } \\
\text { woman }\end{array}$ & 0.40 & 0.10 & 0.50 & 0.60 & 0.40 & 0.10 & 0.60 & 0.40 & 0.00 & 0.00 & & 0.30 \\
\hline $\begin{array}{l}\text { Woman despi- } \\
\text { sed by me }\end{array}$ & -0.40 & -0.50 & -0.50 & 0.40 & -0.20 & -0.20 & 0.00 & 0.00 & 0.20 & 0.10 & 0.00 & \\
\hline
\end{tabular}

${ }^{\star}$ Russian respondents evaluate Azerbaijani woman, and Azerbaijani respondents evaluated Russian woman

Factor analysis employed principal components and varimax rotation (Tabachnick \& Fidell, 2003). 2 factors were singled out in the Azeri sample that could explain 69 and 18\%, respectively, of the total variance. 
Distribution of role positions in the space of the marked factors for the Azerbaijani sample is depicted in Fig. 1.1.

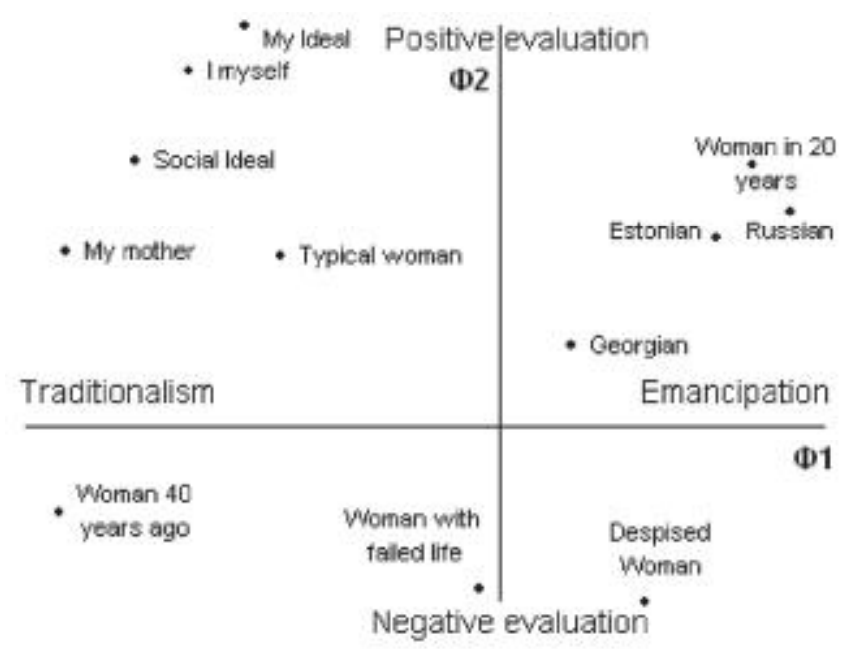

Figure 1.1. Roles in semantic space of acts for Azerbaijanis (F1, F2)

The first bipolar factor included the following acts in one of the poles: to get acquainted with a young man in the street by maintaining the talk initiated by him

to conflict with the husband, since his family demands a lot of time to devote

0.98

to endure the unloved husband for the sake of children, to whom he is attentive and careful

to get married and live far away from the parents

to host an ex-husband's former girlfriend

to run the family budget

to go on vacation with a beloved young man, though is not

2 Factor loadings are presented in the second column. 
to regard living alone as better than getting married

to give the husband a slap for the disrespectful behavior

to go hiking

0.91

to engage in social work

to strive for university education $\quad 0.87$

to do sports regularly $\quad 0.83$

to use jargon words $\quad 0.81$

to keep a dog at home, etc.

0.81

The values of the factor loadings of the acts correspond to the projections of the acts on the axle of this factor and reflect the extent to which the meaning given by this factor, is expressed in each of the acts. The sign of the factor loading has no meaning, and shows the direction of the act toward to the left $(-)$ or to the right $(+)$ pole of the factor.

The opposite pole of the first factor includes the following acts:

to leave school for the sake of the family, if there is such a

choice

not to marry a loved person, because one's parents were

against him

to endure nagging of a mother-in-law rather than to "bring

her down a peg or two"

to consider improper to interfere in the conversation between $\quad-0.94$

the husband and his friends

to think that financial security of one's family is the husband's $\quad-0.89$ responsibility.

Since the roles of a woman in 20 years and a woman of 40 years ago were the most polar in ranking according to this factor, we may call this factor an emancipation or modernity factor, just after the content of one of its poles, or, else, according to the content of both poles, a change of manners in time factor, or simply a time factor.

It is worth noting that any act can be viewed from different positions and assessed as good and as bad. For example, the desire for higher education is highly and positively correlated with the modernity factor and evaluated as a "good" act, but such act as "be unfaithful to her husband in response to his infidelity," also has a high positive correlation with the factor of modernity and is evaluated as a "bad" act (according to our subjects). Factorization allows to separate a single aspect of each factor, 
a "pure line." Therefore, it must be emphasized that grouping acts on the grounds of the first factor should be considered apart from their evaluation components, which (looking ahead) were the basis for the categorization according to the second factor. The grouping of such versatile acts as "to drive," "to send a marriage announcement in the newspaper," "to smoke cigarettes," "to go on vacation with her beloved young man, not being legally married," "to engage in social work," etc., according to the first factor can be explained by the fact that, in addition to its substantive and ethical content, they have (for our subjects) a function of a sign. They are symbols of a certain lifestyle - whether traditional or modern.

Let's consider, for example, such an act as "keeping a dog at home," which entered the first factor at the modernity pole. Taken as such, it can be characterized by the fact that a person loves animals, or that he / she thinks that a dog is a reliable guard, or that he / she has a particular need for a near, but silent creature, etc. But within the context that sets the assignment of this act to certain role positions (I myself, my mother, an ideal woman in my view, a typical woman, etc.) it appears as a keyword, differentiating these role positions according to the factor of modern $\leftrightarrow$ traditional style of life. And here we can find an explanation from the cultural viewpoint. In Azerbaijan, in contrast to Russia, keeping pets (especially dogs) at home is not so popular. This trend, rather characteristic of the European culture, can serve as a guide feature, a sign of a certain lifestyle.

The second factor of the Azeri sample explaining 17.5\% of the total variance, was interpreted as a valuation factor. The reason for this interpretation was the fact that the role positions my ideal, social ideal were the most polar according to this factor, on the one hand, and the despised woman position, on the other hand.

The approved acts were:

to read a newspaper every day

to go to study to another city, despite a prohibition from $\quad 0.71$

parents

to watch the main TV-news program regularly

0.68

to go to theaters, cinemas, exhibitions

0.69

to grow home flowers

0.79

to marry a young man from a different social stratum $\quad 0.69$

to feel a constant need for new people $\quad 0.61$

to drive a car, etc. 
The disapproved acts were:

to beat a child for disobedience $\quad-0.97$

to be late for work or study $\quad-0.81$

to buy expensive jewelry, and the more, the better $\quad-0.80$

to suffer from loneliness $\quad-0.79$

to gossip with neighbors, etc. $\quad-0.72$

It has to be stressed again that many acts that were included in the first emancipation $\leftrightarrow$ traditionalism factor have significant loadings regarding the valuation factor, but their content associated with the "time perspective" eliminates the purely evaluative component. A number of acts, such as "to drive a car," have approximately equal loadings in terms of the second and the first factors. Since the role positions of my ideal woman and the despised woman appear to be the most contrasting according to the valuation factor, it would be appropriate to touch upon the acts attributed to both roles. For example, if a despised woman may "tell her girlfriends frivolous jokes," "exhibit her feelings in public transport," "accept an invitation from an unfamiliar man to call on his home," "initiate a conversation with an attractive guy," "send a marriage announcement to a newspaper," "live her life without entering into marriage," then such behavioral acts are unlikely or are completely eliminated for an ideal woman, whose arsenal includes such acts as "writing poetry" and "to strive for higher education," what is not common for a despised woman. We have revealed only a few acts having similar estimates according to the role positions of an ideal woman and a despised woman. For example, both ideal and despised equally often "share about family quarrels with the parents" and have little differences in the sense of the "not to let enter her husbands' friends which he brought from the restaurant after midnight" act.

The data obtained from the Russian subjects enabled to single out 3 significant factors explaining 55, 24 and 9\% of the total variance, respectively.

The content of the first factor of the Russian sample basically coincides with the content of the first factor relevant for the Azerbaijani sample. The woman of 40 years ago and a woman in 20 years were the most polar positions according to this factor (see Fig. 1.2), and the first factor in the Russian sample got a similar name of an emancipation $\leftrightarrow$ traditionalism factor. 


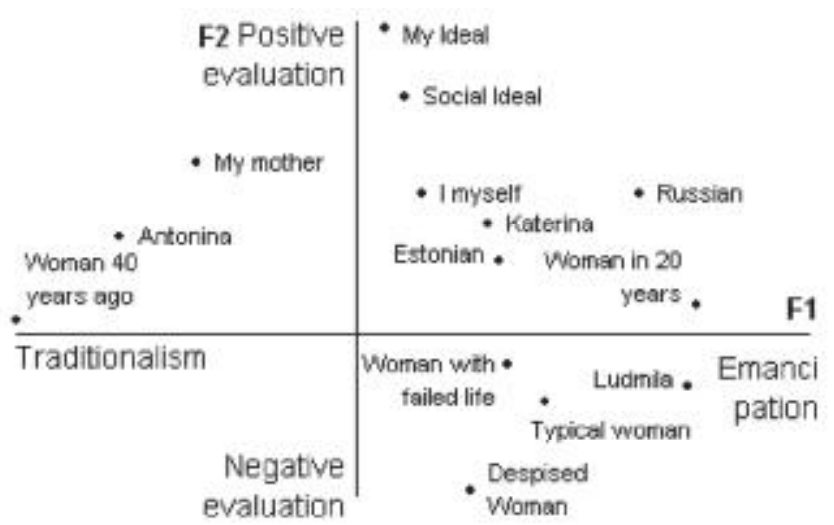

Figure 1.2. Roles and characters of the movie Moscow does not Believe in Tears in the semantics space of acts for Russians (F1, F2)

Grouping of scales according to the first factor of the Russian sample was also consistent with a slight difference in grouping of items according to the first factor of the Azerbaijani sample. Thus, at one pole were the acts like:

to get acquainted with a young man in the street by maintain- $\quad 0.89$ ing the talk initiated by him

to send a marriage announcement to a newspaper $\quad 0.89$

to engage in intimate relations with one's beloved man before $\quad 0.93$

marriage

to run the family budget 0.78

to conflict with the husband, since his family demand a lot of $\quad 0.73$

time to devote

to smoke cigarettes $\quad 0.73$

to go hiking 0.76

to be very involved in public life $\quad 0.72$

The opposite pole of this factor comprised such acts as:

to leave school for family $\quad-0.89$

to consider improper to interfere in the conversation between -0.93

one's husband and his friends

to endure nagging of a mother-in-law rather than to "bring $\quad-0.87$

her down a peg or two"

to think that financial security of one's family is the husband's -0.82

responsibility 
Now let's compare the data from the Azerbaijani and Russian samples from the viewpoint of the first factor. A similar grouping pattern according to the emancipation factor manifests that the interpretation of these acts as expressing the modern and traditional lifestyles in general, coincides in Azerbaijani and Russian cultures. There were only minor differences, though. Thus, "to share with her mother about the relationship with her beloved" and "not to let enter her husbands' friends which he brought from the restaurant after midnight," got to the emancipation pole in the Azerbaijani sample and to the traditionalism pole (patriarchal) in the Russian sample. Along with a similar interpretation of behavior that characterizes the "lifestyle," there are a number of differences judging from the ratings of the two groups. The first striking thing is that the loadings on acts within the first factor are lower for the Russian sample than for the Azerbaijani one. The value of factor loading of an act (i.e. the correlation of the factor with the vector describing the act) shows how significant the meaning (corresponding to the content factor), which supports this act in the minds of the subjects, is. The higher the factor loading of the act is, the more apparently a quality of emancipation or traditionalism (if the sign of loading is opposite) is attributed to such act in this case. For example, "to smoke cigarettes" is $r=0.93$ for the Azeri sample and $r=0.70$ for the Russian sample, "to go hiking" is $r=0.91$ and 0.76 , respectively.

A number of actions that had dominant loadings according to the first modernity $\leftrightarrow$ traditionalism factor in the Azeri sample, fell beyond this factor in the sample of Russian subjects, and were included in other factors that described some other aspects of behavior. Among them "to live one's life without getting married," "not to marry her lover, because the parents did not want," "to conflict with one's husband, since his family demand a lot of time to devote," "to watch the main TV-news program $^{3}$ regularly," etc. For example, "to make one's husband remark in the presence of his friends" act was not so significant for the Russian

\footnotetext{
3 To be more precise, we should add that the item was worded in the questionnaire as "to watch on TV program Vremya regularly." In the Soviet period this program was an official ideological news program. It was broadcasted in prime-time on all TV channels simultaneously. To watch this program in this time meant to be loyal to the Soviet state, and not to be at least apolitical, which was not a good example from official ideological point of view.
} 
sample in terms of emancipation or traditionalism, yet it was included in the valuation factor as an indicator of poor relations between the spouses. We have to underline again that the Azeri sample evaluated this act negatively, but its symbolic value as an indicator of emancipation or traditionalism is more pronounced in the Azerbaijani than in the Russian subjects. As far as the Russian sample is concerned, a set of actions united by the emancipation $\leftrightarrow$ traditionalism factor, was supplemented by a single form of behavior only ("to grow flowers at home"), which was placed in the valuation factor (positive) in the Azeri sample, while in the Russian sample the same was included in the first factor to the traditionalism pole.

The smaller number of acts that fall within in the first factor in the Russian sample, and slightly lower values of factor loadings of these acts result in that the power of the first factor (the factor contribution to the total variance) in the Russian sample is somewhat lower than in Azerbaijani one (55\% for the Russian sample against $69 \%$ for the Azerbaijani).

It is generally known that a factor power reflects the importance of the subjective grounds of categorization corresponding to this factor. Even though subjective significance of the emancipation $\leftrightarrow$ traditionalism feature is high for both samples, it is higher for the Azerbaijanis. They tend to view more acts having heavier weights (factor loadings) from that angle. These results are not unexpected. For a number of socio-historical reasons, peoples of the Caucasus, and especially those historically associated with Islam, were characterized by a sharp polarity of gender roles that cultivated male dominance and female passivity. In our association experiments concentrated on the "ideal woman" key stimulus, the "proud," "unapproachable" qualities were of high frequency in the Azerbaijani sample, while the "polite," "kind," good" qualities were most common among the Russian subjects.

The high sensitivity of the subjects from the Azerbaijani samples to the emancipation $\leftrightarrow$ traditionalism factor (the "proud" and "unapproachable" features, corresponding to "protective" behavior affect this factor as well) does not mean that any Azerbaijani woman chooses the traditionalism pole in her behavior.

Let us have a more detailed examination. Any behavior is the Act when there are a number of alternative interpretations and evaluations of this behavior from the perspective of different moral standards and value 
systems. For example, sitting in the train in the underground is not the Act in this sense, but to sit in the train, if an elderly woman stays nearby is an Act, as this behavior can be evaluated by moral standards. In the 20s of the last century at the Islamic East for a woman to open her face, letting the yashmak cast off, or, if we may give a closer example, in the 60 s to appear in trousers in a big city definitely meant an Act, because it could be interpreted and evaluated in different ways and had a key function. Having become familiar nowadays, these forms of behavior do not cause either approval or censure, and are not Acts. Behavior may be an Act for a person who commits it, and not be such for the others, and vice versa, a person can perform an Act in an unfamiliar culture and remain unaware of this. For example, a tourist, wandered unknowingly into a dangerous area of unfamiliar city in a faraway country, commits a careless act from a position of residents of this city.

Returning to our experiment, we may note that the presence of factors that reflect an important aspect of behavior (in this case, modernity $\leftrightarrow$ traditionalism), does not imply that in all cases a person automatically selects the behavior corresponding to one of the poles of this factor, but shows that among numerous aspects according to which a particular action is evaluated, this aspect is very significant and contributing to the problem of choice. Choice has to be made by a person itself.

The second factor of the Russian sample explaining $24 \%$ of the total variance was interpreted as a valuation factor. The basis for such interpretation was the fact that the role positions of my ideal, social ideal, on the one hand, and a despised woman, on the other hand, were the most polar according to this factor.

Approved acts were:

to strive for university education $\quad 0.73$

to go hiking 0.61

to be hospitable to friends of the husband who is not liked $\quad 0.73$

to read a newspaper every day $\quad 0.76$

to assume that the expression of emotions is permissible only $\quad 0.72$

when being alone

to divorce her beloved husband when found out that he had a $\quad 0.81$

mistress

to do sports regularly $\quad 0.75$

to go to theaters, cinemas, exhibitions 0.64 
Disapproved acts were:

to open and read a letter, which was sent to one's husband by

$-0.98$

an unknown woman

to beat a child for disobedience

$-0.92$

to share with parents thoughts about family quarrels

$-0.83$

to conceal from the husband that bought an expensive thing

$-0.92$

to think that financial security of a family is the husband's

$-0.71$

responsibility

to conflict with the husband, since his family demand a lot of

$-0.68$

time to devote

to regard living alone as better than getting married

$-0.76$

to tell one's colleagues about the conflict with the husband

$-0.86$

to suffer from loneliness at times

$-0.67$

Such differentiating of acts according to the principle of "what is good and what is bad" reflects the regulatory knowledge in the minds of our subjects and, of course, may not always coincide with their actual behavior. For example, assuming that "to open and to read the letter, which came to the husband from an unknown woman" is unethical, our subject is able to perform this act in a real situation and justify it be a possible series of rationalizations like "this is a special case," "because it is very scary," "a letter came from a stranger," or "we do not hide anything from each other," or "in relation to such a wretch one can not behave in another way," etc. It is also possible that due to impulsive curiosity she opens the letter and then will forget about this act by displacing it from memory, or will pay for a breach of ethical standards, which are significant for her, by decrease in self-esteem and self-respect. In reality, when committing a negative act, all these moments are usually present in aggregate, and rarely can a defense mechanism fully protect from negative feelings or, on the contrary, followed by pangs of remorse and self-incrimination, protective mechanisms of self-justification simply do not switch on.

The comparison of acts attributed to the two roles which have polar positions according to the "valuation" factor - an ideal woman from my point of view and a woman despised by me - showed that for a number of acts these role positions were not so contrasting for the Russian sample as for the Azerbaijani. Thus, similar estimates for an ideal woman and $a$ despised woman were the following acts: "to engage in intimate relations with her beloved before marriage," "to get married and live away from 
their parents," "to met an old acquaintance, to invite him home, though her husband is away" etc.

The most contrasting for this role positions appeared to be the following acts: "to resell things in order to earn," "to tell colleagues about quarrels with her husband," "to try keep useful acquaintances," "to hide from her husband, that she bought an expensive thing," "not to marry a loved one, because the parents were against it."

Thus, having in general a similar pattern of "what is good and what is bad," the Azerbaijani women put more emphasis on the disapproval of violations of rules in the intimate personal sphere, while the Russian women disapprove socially unacceptable behaviors.

The weak third factor explaining $9.1 \%$ contribution to the total variance includes the following series of acts according to one of the poles:

to keep animals at home $\quad 0.76$

to be hospitable to friends of the husband whom she does $\quad 0.63$ not like

to keep a housekeeper $\quad 0.61$

to go to disco clubs 0.52

to feel the constant need for new people 0.51

to share with one's mother thoughts about the date relation- $\quad 0.53$

ship with a man

The opposite pole of this factor is represented by the following act:

to experience the futility of one's life $\quad-0.61$

to go away from home when children have a party $\quad-0.58$

A small number of scales included in the weak but nevertheless statistically significant third factor complicate its interpretation. One can suppose that it is associated with ability to contact, sociability, the need to have a living being nearby in opposition to closeness, autism. We will call this factor sociability according to its most pronounced pole.

We should point out that most of the actions included in the third factor also have significant loadings on the previous factors. For example, the act "to be hospitable to friends of her husband, whom she does not like" has a positive factor loading on the valuation factor, which is approximately equal to factor loading on sociability. The act "to have a housekeeper" has a positive factor loading on the sociability and the negative one on the valuation factor. Nevertheless, the presence of the 
third sociability factor, along with the first emancipation $\leftrightarrow$ traditionalism factor, and their general independence from the valuation factor, which incorporates the acts having the most striking component of the evaluation, allows us to construct a two-dimensional space of acts based on these two factors that are more descriptive than evaluating and arrange there the role positions we are interested in.

The presence of such a semantic space from which the most estimating actions were eliminated (factor 2), allows to analyze the roles of my ideal, social ideal, a woman with a failed personal life, and a despised woman not by their evaluative component, where the results is obvious (ideal is good, despised is bad), but to describe these images through the differences in behavior, so to speak, at a level of "style" of behavior. An unexpected result for the Russian sample was the proximity of the typical woman and a woman with a failed personal life role positions. Perhaps, this was affected by the professional identity of our subjects - female students-philologists. An "image of a suffering heroine" is rather typical for the Russian classical literature (recall the heroines of Pushkin, Dostoevsky, Tolstoy, and Chekhov).

The factor loadings distinguished by the experiment within the social and cultural matrices of behavior or, in other words, the constructed subjective, behavioral semantic spaces allow to place in it images of literature and movie characters along with role positions (according to ratings) without any additional factorization. Thus, the characters of the popular movie Moscow does not Believe in Tears directed by Vladimir Menshov were subjected to scaling for the Russian participants (on the basis of our set of actions). Three lives of ordinary girls who came to Moscow from province represent in this film a parable about three ways to achieve personal happiness. The heroines of this film - Katherine, Ludmila and Antonina fall into three different quadrant of our two-dimensional semantic space. The modest plasterer-painter Antonina (actress Ryazanova) that have opted for a reliable family happiness by marrying a guy from her work, was in the semantic space next to the my mother and a woman of 40 years ago role positions. Highly sociable, modern, emancipated Ludmila (actress Muravyova) who was chasing elusive "pie in the sky" all her life was next to the woman with a failed personal life and a typical woman role positions. Katherine, the main heroine of the movie (actress Alentova), shy, strong-willed woman, that became happy through hard work and perseverance, is closest to the myself, my ideal 
woman role positions. This ability to identify the heroine of the movie with the image of an ideal explains the success the movie enjoyed among a wide range of viewers around the world. ${ }^{4}$

To sum it up, we should note that the study was conducted on the material of two ethnic cultures that were well-known to researchers, and the fact that we received intuitively obvious results relevant to ethnographic and demographic data, images of literature and movies shows the relevance of the proposed method applied to less familiar ethnic cultures.

\section{Experiment 2. Comparative analysis \\ of ethnic stereotypes in the field of everyday family behavior according to gender}

The next study aimed to answer the question: were there any differences in the interpretation of actions and specific differences in attitudes to the images of meaningful others due to gender of subjects, or did the stereotypes of behavior of all representatives of an ethnic group (female behavior in our case) not depend on gender. In other words, were the stereotypes, the demands for performing "a female role" common for men and women belonging to a certain national culture and hence common culture stereotypes inherent in the ethnic group as the whole, or are there considerable gender differences in the ideas of desirable and proper of something that is permissible and rejected, and the stereotypes fall into two subcultures: male and female.

To answer this question, further study was conducted on a new contingent of subjects, both male and female representatives of Russian and Azeri ethnicity. 180 people took part in the experiment, including 60 subjects of Azerbaijani females and 30 Azerbaijanis males, and, respectively, 60 Russian females and 30 Russian males.

The procedure of the experiment remained the same as earlier. The subjects rated a possibility to commit an act in relation to the role positions (I, my mother, my ideal woman, etc.) on the Likert six-point scale (from 0 to 5 points). In addition to role positions, the Azerbaijani subjects rated the images of heroines of the Hindi movie Seeta Aur Geeta, and the Russian subjects further evaluated three female characters from the movie Moscow does not Believe in Tears by Menshov.

4 The movie was awarded an Oscar as the best foreign movie. 
Data analysis. Individual records of the subjects were summarized in 4 group data matrix: Azerbaijani men and Azerbaijani women, Russian men and Russian women. These four matrices were analyzed through the factor analysis (principal components method with varimax rotation).

Experimental material. Additional 12 new items were added to the set of items used in the first experiments. This, in particular, judgments concerning ethnic relations ${ }^{5}$ :

to marry a man whose nationality differs from one's own $\quad 21 / 67$

to marry a foreigner and live abroad

Judgments about the artistic taste and preferences:

to love classical music $\quad 69 / 76$

to love folk songs $\quad 81 / 59$

to get involved in rock music $\quad 82 / 55$

to get involved in art $\quad 79 / 81$

A number of new items concerning the value orientations were given in the form of choice of spouse:

to marry an "ordinary," nonintellectual man whose chief

interest is in his home and living a comfortable life and who $\quad 72 / 32$

is skilled in handling domestic tasks

to marry the man of art, bohemian and impulsive, leading

creative, but chaotic life

to marry a beautiful, lucky, well-provided, but smug and

self-confident, spoiled attention and cold to the people man

to marry a young top-manager, having serious carrier plans

$85 / 71$

The comparison of ratings given by Azeri women and Azeri men, when a similar interpretation pattern was present, revealed the shift of images of an ideal woman for men in the direction of even greater traditionalism in comparison with the ratings provided by women themselves. At the level of individual behavior we can note some male underestimating women's ability to perform acts hardly acceptable from men's point of view. Thus, for a number of actions women admitted greater opportunity, if compared with the male estimates. Namely ${ }^{6}$ :

5 A slash means Azerbaijani women / Russian women in the range from 0 to 100 points.

6 Azerbaijani women / Azerbaijani men. 
to marry a man from another social stratum 64/37

to marry a man whose nationality differs from one's own $\quad 31 / 8$

to be unfaithful to the husband after his unfaithfulness $\quad 33 / 8$

to arrange a hen-party with drinks $\quad 40 / 15$

to open and read the letter which was sent to the husband $\quad 57 / 8$

to resell things in order to earn money $\quad 19 / 0$

to buy expensive jewelry, the more, the better $\quad 75 / 32$

and a number of other acts.

At the same time, the Azerbaijani men underestimated the ability of Azerbaijani women to have inner problems and conflicts. For example:

to suffer from loneliness at times $\quad 72 / 37$

to experience the futility of one's life $\quad 61 / 17$

The comparison of ratings given by Russian women and Russian men revealed more similarities within an ethnic group, unlike the Azeri sample. This is obviously due to the fact that the Russian subjects, along with common ethnicity, had the similar specialty (philologists), whereas for the Azeri sample male sample was "diluted" by students in technical fields due to a small number of male student philologists. Some differences in estimates given by men and women from the Russian sample were observed for the following acts ${ }^{7}$ :

to assume that one of the signs of masculinity is to be able to $\quad 72 / 49$ support a family

to have savings separate from the spouse $46 / 21$

to conceal from the husband that you bought an expensive $\quad 21 / 5$

thing

to get acquainted with a young man in the street by $\quad 60 / 37$

maintaining the talk initiated by him

and some other.

The most contrasting assessments of female behavior given by Russian men and Azerbaijani men were the following:

to keep friendly relations with ex-husband after divorce

7 Russian women / Russian men.

8 Azeri men / Russian men. 
to engage in intimate relations with a beloved man before

marriage

to marry a man whose ethnicity differs from her own

to marry a man of art, bohemian and impulsive, leading a

creative, but chaotic life

not to marry a loved person, because one's parents were

$40 / 12$

against him

Discussion of the factor analysis results (Fig. 2.1, 2.2, 2.3, 2.4). To examine the stability of factor structures (structures of categorization), the results of the first and the second experiments were compared. Since a number of items-descriptors were substituted in the second experiment by new ones (see above), a direct comparison of the primary raw data of the two experiments, or comparisons of a correlation matrix or a factor matrix of these two experiments were not possible. Therefore, to compare the similarity ratings of the subjects in the first and second experiments, as well as to compare the semantic space of the subjects of different ethnicities and both genders we used the criterion of similarity of polyhedrons. Positions of the evaluated images were used as vertices of polyhedron.

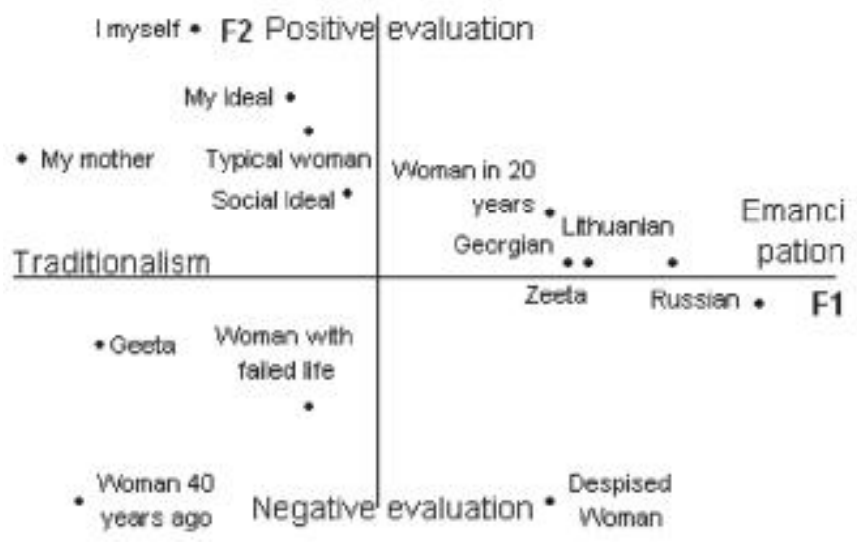

Figure 2.1. Roles and characters of the movie Seeta Aur Geeta in the semantics space of acts (F1, F2) for Azerbaijani women 


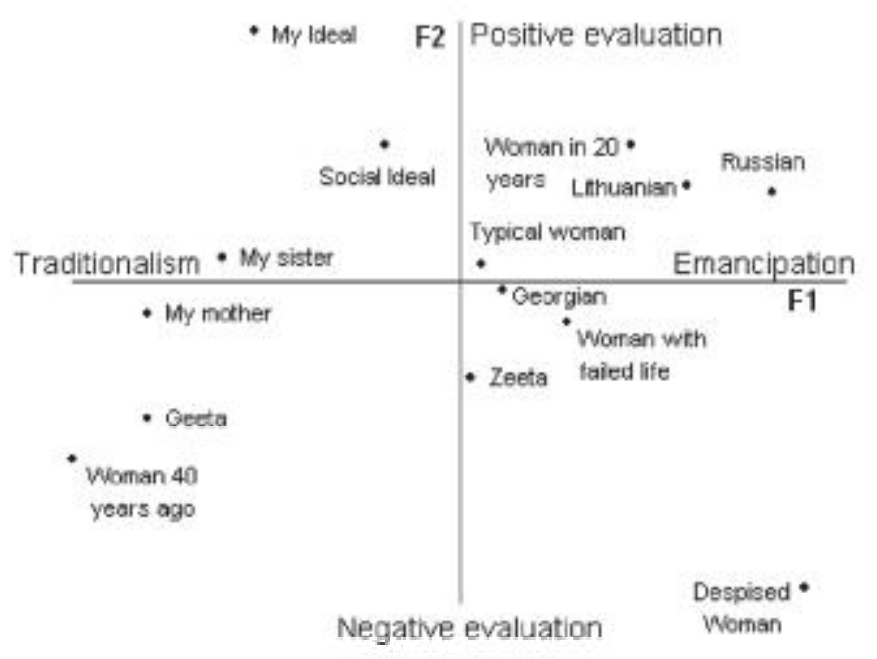

Figure 2.2. Roles and characters of the movie Seeta Aur Geeta in the semantics space of acts (F1, F2) for Azerbaijani men

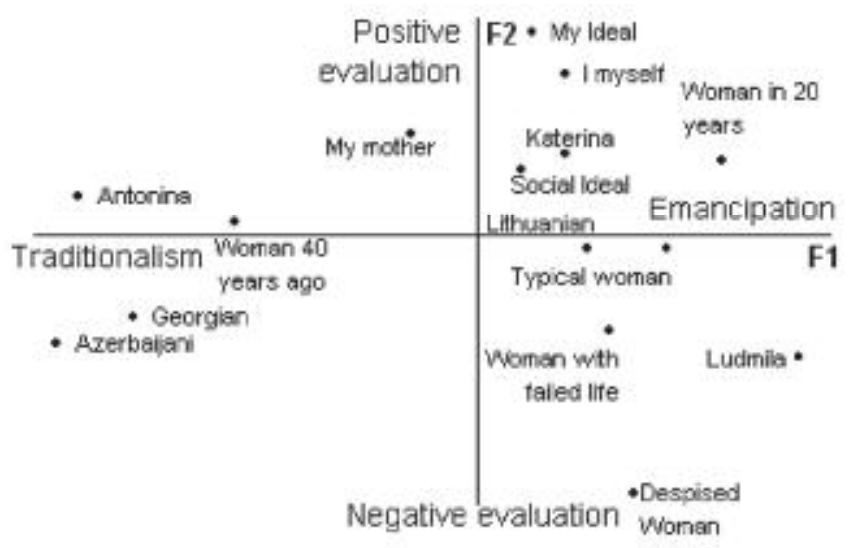

Figure 2.3. Roles and characters of the movie Moscow does not Believe in Tears in the semantics space of acts $(\mathrm{F} 1, \mathrm{~F} 2)$ for Russian women 


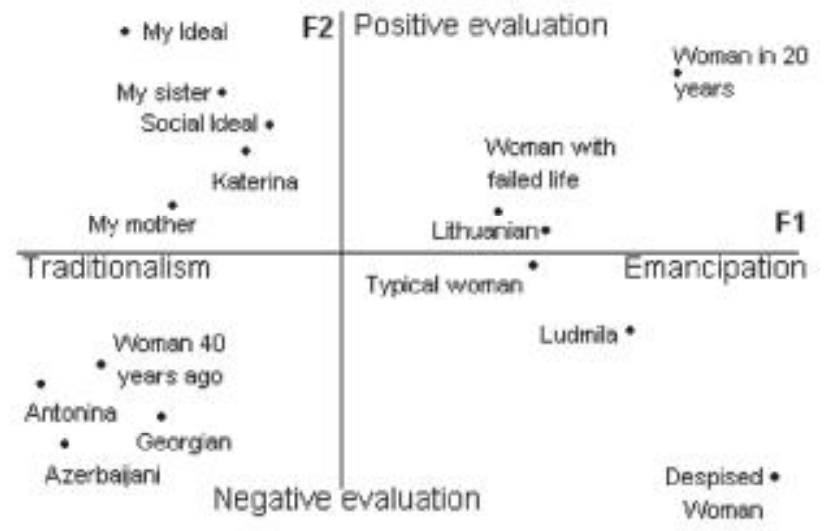

Figure 2.4. Roles and characters of the movie Moscow does not Believe in Tears in the semantics space of acts (F1, F2) for Russian men

The factor structure of the first and the second experiments (test and retest) were stable enough: 0.74 for the Azeri sample and 0.78 for the Russian one (correlations between women in both cases).

Table 2.1

Similarity of semantic spaces of stereotypes of women's behavior for Azerbaijani women (AZW1), Russian women (RUW1) in the $1^{\text {st }}$ experiment, and Azerbaijani women (AZW2), Azerbaijani men (AZM2), Russian women (RUW2), Russian men (RUM2) in the $2^{\text {nd }}$ experiment

\begin{tabular}{|l|ccccc|}
\hline & AZW1 & RUW1 & AZW 2 & AZM2 & RUW2 \\
\cline { 2 - 6 } RUW1 & 0.49 & & & & \\
AZW2 & 0.74 & 0.37 & & & \\
AZM2 & 0.81 & 0.58 & 0.6 & & \\
RUW2 & 0.56 & 0.78 & 0.36 & 0.66 & \\
RUM2 & 0.61 & 0.79 & 0.45 & 0.64 & 0.94 \\
\hline
\end{tabular}

The high similarity (0.94) for Russian women (RUW2) and Russian men (RUM2), and high similarity (0.80) of polygons for Azerbaijani men and women shows that the rating of behaviors for people of different genders united in a single ethnic group is similar and quite different 
in comparison with other ethnic cultures: 0.36 for Azerbaijani and Russian women, and 0.64 for Azerbaijani and Russian men.

Given that the lower threshold value of coefficient of similarity of polygons calculated for surrogate data generated by the Monte-Carlo method is about 0.3 , this makes the results convincing enough and proves invariance of gender stereotyping within the same ethnic group.

Thus, we may fairly conclude that gender stereotypes exist in interpersonal perception and, in a broader sense, that the worldview is common to the entire ethnos and makes it distinguish from other ethnic groups.

It is clear that the technique can provide the items not only in the form of acts in the family and the domestic sphere, but also based on the judgments that affect different valuable aspects of reality, such issues as disarmament, environmental protection, labor and leisure, domestic relations, a place of education and religion in society, attitudes to different types of art and culture.

\section{Experiment 3. Cross-cultural comparison of gender stereotypes between Russian and US citizens}

Aims of the Research: to analyze social problems of women in Russia and the US and their connection with gender stereotypes in the psychological sense.

Procedure of the experiment. The subjects assessed probability of every act selected from 100 positions with the help of a 7-number scale (from -3 to 3) from the viewpoint of the different role positions: I myself, my ideal woman, a happy woman, a despised woman, a typical Russian woman, a typical US woman. The subjects were also asked to fill in an anonymous form, including social information. Results were summed up in different matrixes according to differential parameters (age and gender) for the American and Russian groups under test.

Analysis of correlations. Table 3.1 represents these coefficients. The upper triangle above diagonal contains correlation coefficients grounded on the data collected from the Russian sample. The low triangle contains correlation coefficients grounded on the data collected from the US sample. While comparing the results obtained for each samples, one will note that for the US respondents the ideal and the image of a 
Table 3.1

\begin{tabular}{|c|c|c|c|c|c|c|}
\hline WOMEN'S ROLES & 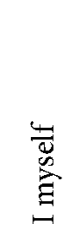 & 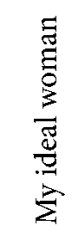 & 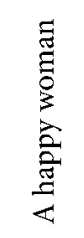 & 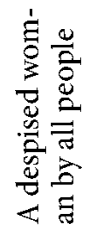 & 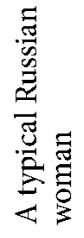 & 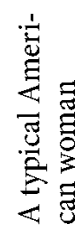 \\
\hline I myself & & 0.32 & -0.23 & -0.32 & -0.10 & -0.45 \\
\hline My ideal woman & 0.41 & & 0.53 & -0.80 & -0.57 & -0.06 \\
\hline A happy woman & 0.10 & 0.56 & & -0.64 & -0.39 & 0.04 \\
\hline A despised woman by all people & -0.55 & -0.76 & -0.72 & & 0.27 & -0.05 \\
\hline A typical Russian woman & -0.52 & -0.63 & -0.41 & 0.40 & & -0.39 \\
\hline A typical American woman & -0.07 & -0.19 & -0.10 & 0.05 & -0.28 & \\
\hline
\end{tabular}

happy woman are more close to the image of myself than that for the Russian respondents. The corresponding coefficients are equal to 0.41 and 0.1 for the Americans and 0.32 and 0.23 for the Russians. Such a result may reflect the higher level of self-respect, self-esteem, and selfsufficiency of the American respondents as compared to women of our country. The correlation coefficients between the images of myself and a happy woman are small but positive for the American respondents while this coefficient is negative for the Russian respondents. This fact may be regarded as one more confirmation of various attitudes to happiness, or to the feeling of being happy in Russia and in the USA. Famous British scholar M. Argyle (1990) in his study of psychology of happiness pointed out that an American respondent estimated oneself as a happier person that she / he really felt. In our country the situation is rather opposite. A Russian respondent is scared to admit him / her self happy and therefore prefers to complain on his / her fate, life, and so on. I.A. Dzhidaryan (1997) in her study of conception of happiness in the Russian mentality says that our well-known persons usually try to avoid the direct answer to the traditional question "Are you happy?" According to Russian mentality, to be happy is a shame. A.S. Pushkin wrote that "being unhappy in family life is peculiar to Russians." In 
the paper mentioned above Dzhidaryan gives the results of a crosscultural research in which Russia is the unsurpassed leader according to the number of unhappy people and leaves Britain, France, and the USA far behind. The number of unhappy among Russian respondents is $45 \%$, among French $25 \%$, among British $1 \%$, and among American respondents is $0 \% ! ! !$

In this connection it is possible to present some results of our research. We asked the Russian respondents: "How much is it peculiar to this or that role to be unsatisfied with oneself?" Such a possibility is estimated by our respondents at the minimal mark (-0.35) for a happy woman and at close to zero (neutral) $(-0.03)$ for an ideal. The estimate given by the American respondents is rather ideological. In some sense they idealize the absence of such a feeling ascribing the minimal mark to an ideal $(-0.22)$ which is less than the mark given to a happy woman $(-0.11)$. To be unsatisfied with oneself is peculiar to a despised woman most of all from the American point of view. In the Russian mentality such a feeling does not cause repulsion and a despised woman got zero mark while a typical Russian woman got the maximal mark.

As it should be expected, there is a negative correlation between a despised woman and positive roles (an ideal and a happy woman) and also the reflexive position myself for the American and Russian samples. Although, supporting our hypothesis that American women have much more self-respect and self-sufficiency as compared with Russian women, they have shown stronger negative correlation between $a$ despised woman and myself $(\rho=-0.55)$ than our Russian respondents $(\rho=-0.32)$.

On the other side, the negative correlation of auto-stereotype (a typical woman of my country) with positive roles and the position myself in both cultures is to some extent unexpected. However, in the American sample the absolute values of these negative coefficients are small and not significant (the corresponding correlation coefficients are equal to $-0.19,-0.10,-0.07)$, while in the Russian sample the negation correlation is significant (the corresponding correlation coefficients are equal to $-0.63,-0.41,-0.52$; the level of significance does not exceed 0.05).

At the same time, the situation with the correlation coefficients of getero-stereotype (a typical woman of another country) with the positive and negative roles is a mirror image. The Russian respon- 
dents gave correlation coefficients practically equal to zero and the correlation coefficient between a typical American woman and a happy woman was even positive. The American respondents shown than the correlation coefficient between a typical Russian woman and $a$ despised woman is positive while between an ideal or a happy woman are negative $(\mathrm{p}<0.01)$. To all appearance, the more positive attitude of the Russian respondents to a typical American woman is a consequence of an image of the US as a "Heaven on the Earth" (high life standards, democratic freedoms, and comforts) ingrained in minds of Russians. ${ }^{9}$ For the American respondents Russia is (though it is still a great country) a country of permanent cataclysms, revolutions, force major situations, low life standards, high level of criminality, where people cannot live as they wish and should always struggle for their existence.

Table 3.2.

\begin{tabular}{|c|c|c|c|c|c|c|c|c|c|c|}
\hline \begin{tabular}{|} 
WOMEN'S ROLES, \\
ACTIONS, DEEDS, \\
LIVING SITUATIONS
\end{tabular} & 悹 & & 胥 & & है & 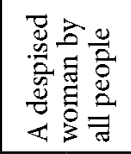 & 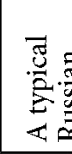 & 焉 & : & 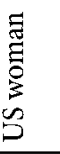 \\
\hline & RU US & RU & US & RU & US & RU US & RU & US & RU & US \\
\hline $\begin{array}{l}\text { 1. To devote one's } \\
\text { life to a family, be } \\
\text { a housewife. }\end{array}$ & $0.15 \quad 0.28$ & 0.30 & 0.24 & 0.73 & 0.36 & $-0.61-0.29$ & 0.66 & 0.34 & -0.01 & 0.14 \\
\hline $\begin{array}{l}\text { 2. To devote one's } \\
\text { life to a professional } \\
\text { career. }\end{array}$ & $0.36 \quad 0.42$ & 0.49 & 0.53 & 0.55 & 0.55 & $-0.47-0.08$ & 0.07 & -0.01 & 1.05 & 0.52 \\
\hline $\begin{array}{l}\text { 3. To have higher } \\
\text { education and / or } \\
\text { a profession that } \\
\text { requires highly de- } \\
\text { veloped skills. }\end{array}$ & 1.380 .51 & 1.55 & 0.74 & 1.19 & 0.64 & $-0.45-0.20$ & 0.58 & 0.05 & 1.10 & 0.60 \\
\hline $\begin{array}{l}\text { 4. To work in an un- } \\
\text { skilled, low paying } \\
\text { job. }\end{array}$ & $-0.89-0.51$ & -1.29 & -0.55 & -1.15 & -0.38 & 0.420 .21 & 0.41 & 0.20 & -0.59 & 0.01 \\
\hline $\begin{array}{l}\text { 5. To work in educa- } \\
\text { tion (tutor, teacher, } \\
\text { etc.). }\end{array}$ & $\begin{array}{ll}0.31 & 0.27\end{array}$ & 0.49 & 0.28 & 0.71 & 0.48 & $-0.75-0.22$ & 0.81 & 0.18 & 0.59 & 0.49 \\
\hline
\end{tabular}

9 This situation was in the time of the experiment (90s). 


\begin{tabular}{|c|c|c|c|c|c|c|}
\hline $\begin{array}{l}\text { 6. To work as a sales- } \\
\text { person or in a service } \\
\text { industry (hairdressers, } \\
\text { waitresses, etc.). }\end{array}$ & $-0.62-0.12$ & $-0.57-0.18$ & $0.01 \quad 0.19$ & 0.320 .06 & $\begin{array}{ll}0.77 & 0.22\end{array}$ & 0.590 .34 \\
\hline 7. To work in Science. & $0.21-0.08$ & $0.54 \quad 0.26$ & $0.57 \quad 0.42$ & $-0.58-0.16$ & 0.140 .08 & $0.41 \quad 0.26$ \\
\hline $\begin{array}{l}\text { 8. To practice medi- } \\
\text { cine (doctors, nurses). }\end{array}$ & $-0.02 \quad 0.09$ & $0.66 \quad 0.42$ & 0.710 .55 & $-0.66-0.25$ & $\begin{array}{ll}0.79 & 0.09\end{array}$ & 0.720 .43 \\
\hline $\begin{array}{l}\text { 9. To work in a factory } \\
\text { or mill. }\end{array}$ & $-0.87-0.51$ & $-0.91-0.49$ & $-0.36-0.24$ & 0.190 .11 & $0.64 \quad 0.24$ & $-0.27-0.07$ \\
\hline $\begin{array}{l}\text { 10. To work in agri- } \\
\text { culture. }\end{array}$ & $-0.87-0.21$ & $-0.73-0.12$ & $0.05 \quad 0.22$ & $0.02-0.02$ & 0.650 .26 & 0.040 .06 \\
\hline $\begin{array}{l}11 . \text { To be a business- } \\
\text { woman. }\end{array}$ & $0.23 \quad 0.27$ & $0.56 \quad 0.41$ & 0.560 .57 & $-0.31-0.01$ & $\begin{array}{ll}0.13 & 0.09\end{array}$ & $\begin{array}{ll}1.09 & 0.58\end{array}$ \\
\hline $\begin{array}{l}\text { 12. To have a tradi- } \\
\text { tionally male profes- } \\
\text { sion. }\end{array}$ & -1.100 .14 & $\begin{array}{|ll|}-0.97 & 0.22\end{array}$ & \begin{tabular}{|ll|l}
-0.50 & 0.39
\end{tabular} & $\begin{array}{|ll|}-0.30 & 0.10\end{array}$ & $\begin{array}{|ll|}-0.37 & 0.06\end{array}$ & $\begin{array}{ll}0.19 & 0.29\end{array}$ \\
\hline $\begin{array}{l}\text { 13. To be a leader (of } \\
\text { an enterprise, organi- } \\
\text { zation, agency). }\end{array}$ & $-0.06 \quad 0.32$ & $0.33 \quad 0.52$ & 0.350 .62 & $-0.57-0.11$ & $0.05-0.03$ & $0.85 \quad 0.41$ \\
\hline one's own & 0.040 .31 & 0.520 .48 & 0.450 .59 & $-0.32-0.08$ & $-0.02-0.07$ & $\begin{array}{ll}1.06 & 0.42\end{array}$ \\
\hline $\begin{array}{l}\text { 15. To worl } \\
\text { civil servic }\end{array}$ & 0.910 .05 & 0.670 .11 & $0.71 \quad 0.32$ & $0.03-0.10$ & $1.05 \quad 0.12$ & $0.68 \quad 0.29$ \\
\hline $\begin{array}{l}\text { 16. To work in the } \\
\text { mass media (journal- } \\
\text { ist, editor, broad- } \\
\text { caster). }\end{array}$ & $0.00-0.01$ & $0.58 \quad 0.33$ & $0.74 \quad 0.49$ & $-0.48-0.09$ & $\begin{array}{ll}0.23 & 0.07\end{array}$ & 0.880 .45 \\
\hline $\begin{array}{l}\text { ork in the } \\
\text { ress, painter, } \\
\text { tc.). }\end{array}$ & -0.070 .06 & 0.640 .26 & $0.83 \quad 0.55$ & $-0.37-0.08$ & 0.210 .14 & 0.520 .40 \\
\hline $\begin{array}{l}\text { 18. To live without } \\
\text { working relying } \\
\text { on help from one's } \\
\text { parents. }\end{array}$ & $-1.41-0.23$ & $-1.43-0.26$ & $-0.89-0.04$ & $0.72 \quad 0.11$ & $-0.38-0.02 \mid$ & $-0.67-0.01$ \\
\hline $\begin{array}{l}\text { 19. To } \\
\text { fessio }\end{array}$ & $-1.41-0.39$ & $-1.00-0.27$ & -0.660 .22 & $-0.48-0.01$ & $-0.52-0.18$ & $\begin{array}{ll}0.30 & 0.07\end{array}$ \\
\hline $\begin{array}{l}\text { 20. } \mathrm{Tc} \\
\text { to a re }\end{array}$ & $-1.45-0.28$ & $-1.31-0.32$ & $\begin{array}{ll}-0.61 & 0.12\end{array}$ & $-0.40-0.22$ & -0.420 .06 & $-0.43-0.01$ \\
\hline $\begin{array}{l}\text { 21. To become a pro- } \\
\text { fessional sportsman. }\end{array}$ & $-1.22-0.52$ & $-0.57-0.11$ & $0.00 \quad 0.27$ & $-0.41-0.16$ & $-0.13-0.06 \mid$ & $0.28 \quad 0.10$ \\
\hline $\begin{array}{l}22 \text {. To become a } \\
\text { model and/or to take } \\
\text { part in beauty compe- } \\
\text { titions. }\end{array}$ & $-0.94-0.27$ & $\begin{array}{ll}-0.18 & 0.23\end{array}$ & 0.280 .45 & $-0.20-0.14$ & $0.01-0.01$ & 0.620 .32 \\
\hline 23. To be a prostitute. & $-1.61-0.85$ & $-1.60-0.86$ & $-1.37-0.64$ & $0.88 \quad 0.36$ & $-0.53-0.24$ & $-0.31-0.42$ \\
\hline
\end{tabular}




\begin{tabular}{|c|c|c|c|c|c|c|}
\hline \begin{tabular}{|l|} 
24. To marry an "or- \\
dinary," nonintellec- \\
tual man whose chief \\
interest is in his home \\
and living a comfort- \\
able life and who is \\
skilled in handling \\
domestic tasks.
\end{tabular} & $0.44 \quad 0.04$ & $0.35-0.08$ & 0.820 .09 & $-0.27-0.02$ & $1.06 \quad 0.14$ & $0.61 \quad 0.10$ \\
\hline $\begin{array}{l}\text { 25. To marry an ar- } \\
\text { tist (musician, poet, } \\
\text { artist). }\end{array}$ & $\begin{array}{ll}-0.03 & 0.05\end{array}$ & $0.29 \quad 0.19$ & 0.650 .41 & $-0.19-0.01$ & $0.14 \quad 0.14$ & $\begin{array}{ll}0.47 & 0.29\end{array}$ \\
\hline $\begin{array}{l}\text { 26. To marry a busi- } \\
\text { nessman. }\end{array}$ & $0.24 \quad 0.32$ & $0.48 \quad 0.44$ & 0.660 .56 & 0.130 .02 & 0.530 .23 & $\begin{array}{ll}1.07 & 0.48\end{array}$ \\
\hline $\begin{array}{l}\text { 27. To marry a poli- } \\
\text { tician. }\end{array}$ & $-0.38-0.05$ & -0.040 .03 & $0.21 \quad 0.32$ & $\begin{array}{ll}-0.22 & 0.07\end{array}$ & $\begin{array}{ll}0.04 & 0.17\end{array}$ & 0.710 .33 \\
\hline $\begin{array}{l}28 \text {. To marry a mili- } \\
\text { tary serviceman. }\end{array}$ & $-0.33-0.08$ & $-0.15-0.05$ & 0.130 .29 & -0.120 .02 & $\begin{array}{ll}0.64 & 0.37\end{array}$ & $\begin{array}{ll}0.43 & 0.24\end{array}$ \\
\hline $\begin{array}{l}\text { 29. To marry a blue } \\
\text { collar worker. }\end{array}$ & -0.400 .10 & -0.450 .05 & 0.200 .26 & -0.040 .03 & $0.70 \quad 0.30$ & $\begin{array}{ll}0.27 & 0.28\end{array}$ \\
\hline $\begin{array}{l}\text { 30. To marry } \\
\text { a farmer. }\end{array}$ & $-0.63-0.19$ & $-0.39-0.17$ & $0.27 \quad 0.20$ & $-0.18-0.15$ & $0.41 \quad 0.34$ & 0.510 .13 \\
\hline $\begin{array}{l}\text { 31. To marry a ce- } \\
\text { lebrity (in sports, } \\
\text { movies). }\end{array}$ & $\begin{array}{ll}-0.57 & 0.02\end{array}$ & $\begin{array}{ll}-0.18 & 0.09\end{array}$ & $\begin{array}{ll}0.26 & 0.47\end{array}$ & -0.070 .03 & $\begin{array}{ll}-0.01 & 0.04\end{array}$ & 0.630 .39 \\
\hline $\begin{array}{l}\text { 32. To marry a mem- } \\
\text { ber of a criminal } \\
\text { group. }\end{array}$ & $-1.14-0.71$ & $-1.19-0.64$ & $-0.80-0.41$ & $\begin{array}{ll}0.51 & 0.18\end{array}$ & $-0.42-0.16$ & $-0.32-0.26$ \\
\hline $\begin{array}{l}\text { 33. To marry a man } \\
\text { who devotes his life to } \\
\text { science. }\end{array}$ & $0.18-0.03$ & 0.360 .01 & $0.42 \quad 0.22$ & $-0.34-0.19$ & $0.31 \quad 0.15$ & $\begin{array}{ll}0.41 & 0.14\end{array}$ \\
\hline $\begin{array}{l}\text { 34. To marry a deeply } \\
\text { religious man. }\end{array}$ & $-0.82-0.04$ & $-0.51-0.10$ & $\begin{array}{ll}-0.02 & 0.26\end{array}$ & $-0.33-0.19$ & $\begin{array}{ll}-0.03 & 0.19\end{array}$ & $\begin{array}{ll}0.17 & 0.19\end{array}$ \\
\hline $\begin{array}{l}\text { 35. To marry a } \\
\text { foreigner and live } \\
\text { abroad. }\end{array}$ & $-0.32-0.20$ & $0.03-0.11$ & $0.52 \quad 0.34$ & $0.52 \quad 0.03$ & $0.38 \quad 0.16$ & $0.17 \quad 0.14$ \\
\hline \begin{tabular}{|l|}
66. To marry a man \\
whose nationality dif- \\
fers from one's own. \\
\end{tabular} & $0.33 \quad 0.00$ & $\begin{array}{ll}0.52 & 0.09\end{array}$ & $0.67 \quad 0.29$ & $0.37 \quad 0.08$ & $0.42 \quad 0.10$ & $\begin{array}{ll}0.65 & 0.20\end{array}$ \\
\hline $\begin{array}{l}\text { 37. To marry a man } \\
\text { whose race differs } \\
\text { from one's own. } \\
\end{array}$ & $-0.63-0.30$ & $-0.33-0.19$ & $0.10 \quad 0.18$ & $0.31 \quad 0.14$ & $-0.17-0.03$ & 0.310 .05 \\
\hline $\begin{array}{l}\text { 38. To marry a belo- } \\
\text { ved man who has very } \\
\text { low income and no } \\
\text { prospects for increa- } \\
\text { sing it. }\end{array}$ & $0.31-0.26$ & $0.16-0.19$ & $0.15-0.06$ & -0.430 .06 & $0.44 \quad 0.13$ & $-0.44-0.14$ \\
\hline
\end{tabular}




\begin{tabular}{|c|c|c|c|c|c|c|c|}
\hline $\begin{array}{l}\text { 39. To marry without } \\
\text { love, marrying for } \\
\text { money. }\end{array}$ & $-0.59-0.59$ & $-0.69-0.64$ & $-0.54-0.32$ & 0.69 & 0.30 & $0.26 \quad 0.00$ & $0.67 \quad 0.13$ \\
\hline $\begin{array}{l}\text { 40. To marry a man } \\
\text { of higher social status } \\
\text { than one's own. }\end{array}$ & $0.63 \quad 0.24$ & 0.720 .25 & 0.760 .35 & 0.26 & 0.26 & $0.63 \quad 0.24$ & $\begin{array}{ll}0.88 & 0.39\end{array}$ \\
\hline $\begin{array}{l}\text { 41. To live with a man } \\
\text { without being legally } \\
\text { married to him. }\end{array}$ & $0.44-0.08$ & 0.410 .03 & $0.58 \quad 0.20$ & 0.53 & 0.32 & $0.24-0.03$ & $\begin{array}{ll}0.91 & 0.27\end{array}$ \\
\hline $\begin{array}{l}\text { 42. To be kept by a } \\
\text { well-off man. }\end{array}$ & $\begin{array}{ll}-0.49 & 0.03\end{array}$ & $\begin{array}{ll}-0.50 & 0.04\end{array}$ & $\begin{array}{ll}-0.08 & 0.20\end{array}$ & 0.77 & 0.21 & $0.09 \quad 0.15$ & $0.43 \quad 0.23$ \\
\hline $\begin{array}{l}\text { 43. To divorce one's } \\
\text { husband because he is } \\
\text { an alcoholic. }\end{array}$ & $0.94 \quad 0.24$ & $\begin{array}{ll}0.82 & 0.37\end{array}$ & $0.80 \quad 0.33$ & -0.19 & 0.08 & $0.24 \quad 0.00$ & 0.720 .29 \\
\hline $\begin{array}{l}\text { 44. To divorce one's } \\
\text { husband who has } \\
\text { become an invalid. }\end{array}$ & $-0.72-0.26 \mid$ & $-0.92-0.29$ & $-0.50-0.06$ & 0.67 & 0.22 & $-0.37-0.10$ & -0.010 .10 \\
\hline $\begin{array}{l}\text { 45. To divorce a } \\
\text { husband after he is } \\
\text { diagnosed as having } \\
\text { AIDS. }\end{array}$ & $-0.10-0.34$ & $-0.27-0.34$ & $-0.07-0.08$ & 0.56 & 0.27 & $0.18-0.09$ & $\begin{array}{ll}0.30 & 0.07\end{array}$ \\
\hline $\begin{array}{l}\text { 46. To regard living } \\
\text { alone as better than } \\
\text { getting married. }\end{array}$ & $-0.68-0.32$ & $-0.72-0.33$ & $-0.65-0.08$ & 0.33 & 0.22 & $-0.50-0.07$ & $0.28 \quad 0.02$ \\
\hline $\begin{array}{l}\text { 47. To divorce an un- } \\
\text { loved husband while } \\
\text { having children. }\end{array}$ & $0.57-0.20$ & $\begin{array}{lll}0.64 & -0.17\end{array}$ & $0.62-0.04$ & -0.06 & 0.18 & $\begin{array}{lll}0.17 & -0.09\end{array}$ & $0.74 \quad 0.13$ \\
\hline $\begin{array}{l}\text { 48. To remain in a } \\
\text { marriage where one is } \\
\text { experiencing violence } \\
\text { from one's husband. }\end{array}$ & $-1.25-0.64$ & $-1.33-0.67$ & $-1.29-0.62$ & 0.51 & 0.11 & $0.18-0.09$ & $-0.70-0.23$ \\
\hline $\begin{array}{l}\text { 49. To remain in a } \\
\text { marriage where one's } \\
\text { daughter is experienc- } \\
\text { ing violence from } \\
\text { her stepfather, one's } \\
\text { current husband. }\end{array}$ & $-1.51-0.64$ & $-1.56-0.67$ & $-1.52-0.56$ & 0.51 & 0.14 & $-0.46-0.13$ & $-0.74-0.16$ \\
\hline $\begin{array}{l}\text { 50. To build up family } \\
\text { relationships on the } \\
\text { principle of equal } \\
\text { rights. }\end{array}$ & 1.290 .44 & 1.300 .54 & $\begin{array}{ll}1.21 & 0.53\end{array}$ & -0.44 & -0.08 & $0.54 \quad 0.17$ & 1.100 .44 \\
\hline $\begin{array}{l}51 \text {. To be the head of } \\
\text { the family. }\end{array}$ & $-0.03 \quad 0.13$ & $\begin{array}{ll}-0.08 & 0.08\end{array}$ & $0.03 \quad 0.32$ & -0.25 & 0.03 & $\begin{array}{lll}0.25 & -0.04\end{array}$ & $\begin{array}{ll}0.47 & 0.21\end{array}$ \\
\hline $\begin{array}{l}\text { 52. To have savings } \\
\text { separate from one's } \\
\text { spouse. }\end{array}$ & $0.46 \quad 0.05$ & $0.51 \quad 0.04$ & $\begin{array}{lll}0.55 & 0.30\end{array}$ & 0.41 & 0.18 & $0.30-0.05$ & $1.14 \quad 0.31$ \\
\hline
\end{tabular}




\begin{tabular}{|c|c|c|c|c|c|c|c|}
\hline \begin{tabular}{l|} 
53. To think that \\
financial security of \\
one's family is the hus- \\
band's responsibility.
\end{tabular} & $\begin{array}{lll}0.50 & -0.10\end{array}$ & $\begin{array}{lll}0.47 & -0.11\end{array}$ & $\begin{array}{ll}0.68 & 0.09\end{array}$ & 0.47 & 0.19 & $\begin{array}{ll}0.60 & 0.22\end{array} \mid$ & $\begin{array}{ll}0.51 & 0.14\end{array}$ \\
\hline $\begin{array}{l}54 \text {. To tolerate the } \\
\text { possibility of the hus- } \\
\text { band's infidelity. }\end{array}$ & $-0.64-0.29$ & $-0.59-0.26$ & $-0.80-0.20$ & 0.45 & 0.06 & $-0.15 \quad 0.01$ & $\begin{array}{lll}0.27 & -0.09\end{array}$ \\
\hline $\begin{array}{l}55 . \text { To have sexual } \\
\text { relations before mar- } \\
\text { riage. }\end{array}$ & $\begin{array}{ll}0.49 & 0.22\end{array}$ & $0.34 \quad 0.19$ & $\begin{array}{ll}0.49 & 0.33\end{array} \mid$ & 0.63 & 0.37 & $\begin{array}{ll}0.46 & 0.10\end{array}$ & $\begin{array}{ll}0.99 & 0.48\end{array}$ \\
\hline $\begin{array}{l}\text { 56. To be unfaithful to } \\
\text { one's husband. }\end{array}$ & $-0.59-0.67 \mid$ & $-0.79-0.76$ & $|-0.61-0.41|$ & 0.72 & 0.35 & $\left|\begin{array}{ll}0.11 & -0.30\end{array}\right|$ & 0.530 .00 \\
\hline $\begin{array}{l}\text { 57. To start a love } \\
\text { affair with someone } \\
\text { from one's workplace. }\end{array}$ & $-0.48-0.50$ & $-0.51-0.53$ & $|-0.38-0.26|$ & 0.53 & 0.28 & $\left|\begin{array}{ll}0.20 & -0.14\end{array}\right|$ & $\begin{array}{ll}0.51 & 0.07\end{array}$ \\
\hline $\begin{array}{l}\text { 58. To guide one's } \\
\text { own behavior by the } \\
\text { traditions and moral } \\
\text { norms accepted by } \\
\text { one's society. } \\
\end{array}$ & $0.55 \quad 0.30$ & $0.55 \quad 0.27$ & $\left|\begin{array}{ll}0.67 & 0.29\end{array}\right|$ & -0.45 & $5-0.02$ & $\begin{array}{ll}0.85 & 0.33\end{array} \mid$ & $\begin{array}{ll}0.76 & 0.33\end{array}$ \\
\hline $\begin{array}{l}\text { 59.To agree in advance } \\
\text { with one's parents' } \\
\text { choice of a fiancé. }\end{array}$ & $-1.32-0.25$ & $-1.18-0.31$ & $|-0.95-0.16|$ & 0.04 & 0.01 & $\left|\begin{array}{ll}-0.49 & 0.09\end{array}\right|$ & $-0.54-0.17$ \\
\hline $\begin{array}{l}\text { 60. To believe that } \\
\text { parents have lack the } \\
\text { right to interfere in } \\
\text { their children's private } \\
\text { lives. }\end{array}$ & $0.76-0.10$ & $0.63-0.08$ & $\begin{array}{ll}0.60 & 0.02\end{array}$ & 0.08 & 0.07 & $\left|\begin{array}{ll}0.37 & -0.06\end{array}\right|$ & $\begin{array}{ll}0.81 & 0.09\end{array}$ \\
\hline $\begin{array}{l}\text { 61.To marry early in } \\
\text { order to be free of } \\
\text { parental supervision } \\
\text { and control. }\end{array}$ & $-0.46-0.34$ & $-0.59-0.43$ & $-0.40-0.25 \mid$ & 0.52 & 0.20 & $\left|\begin{array}{ll}0.37 & 0.02\end{array}\right|$ & $\begin{array}{ll}0.26 & 0.00\end{array}$ \\
\hline $\begin{array}{l}\text { 62.Not having } \\
\text { children because one } \\
\text { thinks it is better to } \\
\text { live without them. }\end{array}$ & $-1.39-0.49$ & $-1.28-0.46$ & $-1.27-0.21$ & 0.69 & 0.22 & $\mid-0.87-0.12$ & $-0.24-0.04$ \\
\hline $\begin{array}{l}\text { 63. To leave one's } \\
\text { baby in the maternity } \\
\text { hospital if one lacks } \\
\text { financial support from } \\
\text { somebody. }\end{array}$ & $-1.49-0.70$ & $-1.46-0.69$ & $-1.33-0.45$ & 0.95 & 0.30 & $-0.72-0.15$ & $-0.54-0.18$ \\
\hline $\begin{array}{l}\text { 64. To leave one's baby, } \\
\text { an invalid, in the care } \\
\text { of an agency. }\end{array}$ & $-0.94-0.62$ & $-1.13-0.61$ & $-0.95-0.40$ & 0.90 & 0.28 & $\mid-0.49-0.13$ & $-0.40-0.17$ \\
\hline
\end{tabular}




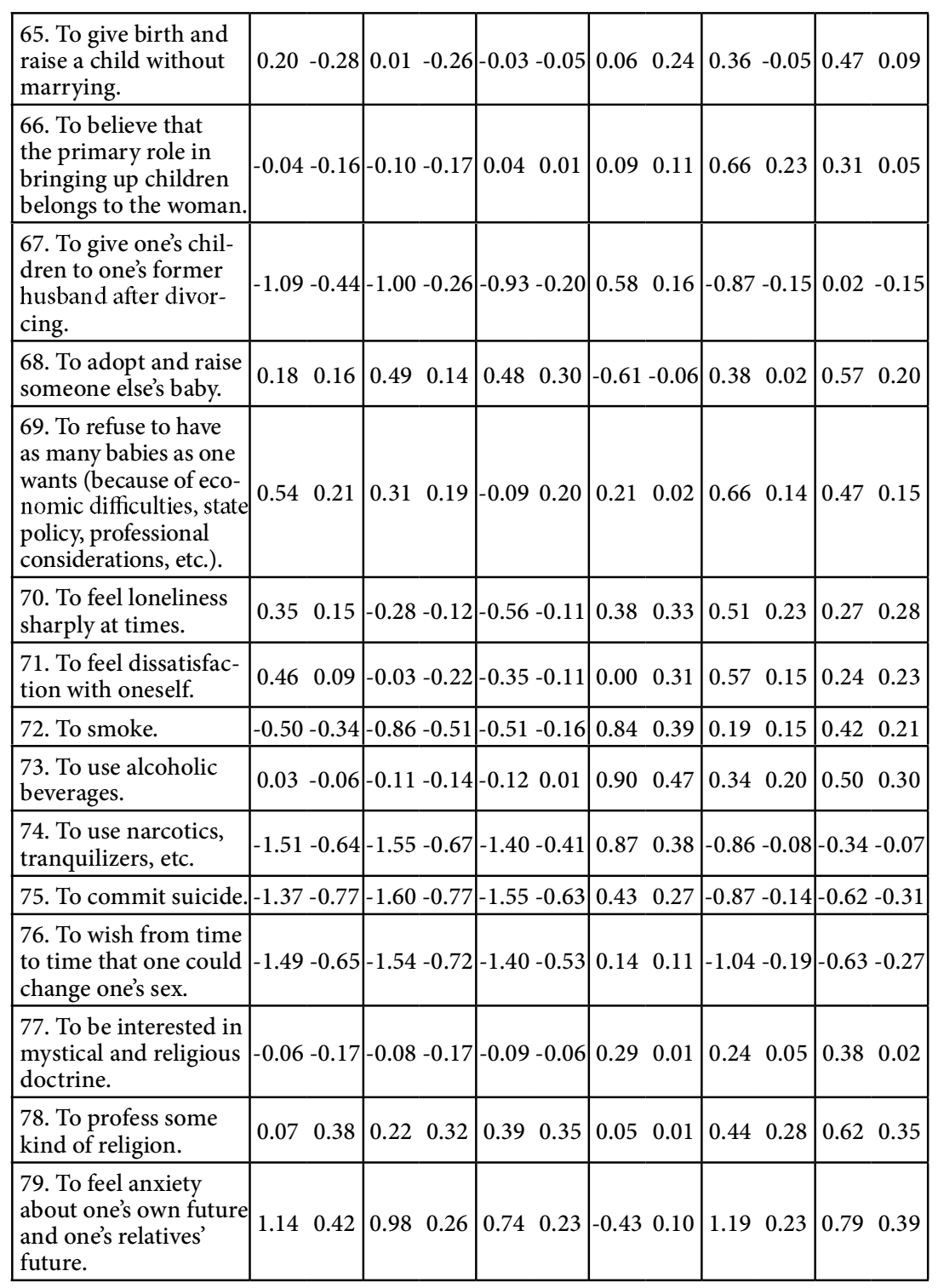




\begin{tabular}{|c|c|c|c|c|c|c|c|}
\hline $\begin{array}{l}80 . \text { To give attention } \\
\text { to one's appearance } \\
\text { and health. }\end{array}$ & $1.24 \quad 0.68$ & $\begin{array}{ll}1.50 & 0.69\end{array}$ & 1.500 .63 & $-0.20-0.07$ & $0.73 \quad 0.22$ & 1.38 & 0.60 \\
\hline $\begin{array}{l}81 . \text { To engage in } \\
\text { sports and / or to } \\
\text { travel. }\end{array}$ & $0.66 \quad 0.55$ & 1.150 .66 & 1.100 .62 & $-0.44-0.06$ & $0.24 \quad 0.16$ & 1.08 & 0.53 \\
\hline $\begin{array}{l}\text { 82. To be fond of } \\
\text { needlework (sewing, } \\
\text { embroidery, knitting). }\end{array}$ & 0.720 .08 & 1.020 .13 & 1.100 .21 & $-0.38-0.08$ & $1.05 \quad 0.26$ & 0.29 & 0.19 \\
\hline $\begin{array}{l}\text { 83. To be engrossed } \\
\text { with cooking (art of } \\
\text { cookery). }\end{array}$ & $0.85 \quad 0.31$ & 1.130 .45 & 1.190 .40 & $-0.38-0.08$ & $1.07 \quad 0.30$ & 0.50 & 0.31 \\
\hline $\begin{array}{l}\text { 84. To devote free } \\
\text { time to creative works, } \\
\text { art. }\end{array}$ & $0.54 \quad 0.28$ & $\begin{array}{ll}1.06 & 0.37\end{array}$ & 1.060 .40 & $-0.59-0.10$ & $0.20 \quad 0.17$ & 0.61 & 0.27 \\
\hline $\begin{array}{l}85 . \text { To take part in } \\
\text { public and political } \\
\text { activities. }\end{array}$ & $\begin{array}{lll}-0.27 & 0.09\end{array}$ & $\begin{array}{ll}-0.01 & 0.21\end{array}$ & $0.05 \quad 0.30$ & $-0.33-0.09$ & $-0.06-0.02$ & 0.69 & 0.26 \\
\hline $\begin{array}{l}86 . \text { To carry out } \\
\text { charitable actions in } \\
\text { public-social orga- } \\
\text { nizations (asylums, } \\
\text { shelters, etc.). }\end{array}$ & $0.01 \quad 0.30$ & $0.48 \quad 0.26$ & $\begin{array}{ll}0.50 & 0.38\end{array}$ & $-0.88-0.16$ & 0.120 .11 & 0.72 & 0.24 \\
\hline $\begin{array}{l}\text { 87. To be a member of } \\
\text { a women's organiza- } \\
\text { tion. }\end{array}$ & $-0.35 \quad 0.13$ & -0.140 .13 & $\begin{array}{ll}0.18 & 0.23\end{array}$ & $-0.39-0.01$ & $-0.09-0.01$ & 0.86 & 0.27 \\
\hline $\begin{array}{l}88 . \text { To be strongly } \\
\text { against abortions. }\end{array}$ & $\begin{array}{ll}-0.61 & 0.09\end{array}$ & -0.420 .02 & $\begin{array}{ll}-0.21 & 0.15\end{array}$ & $-0.35-0.02$ & -0.290 .03 & 0.01 & 0.09 \\
\hline $\begin{array}{l}89 . \text { To consider the } \\
\text { decision about abor- } \\
\text { tion to be a woman's } \\
\text { prerogative. }\end{array}$ & $0.73 \quad 0.30$ & $\begin{array}{lll}0.67 & 0.27\end{array}$ & $\begin{array}{ll}0.63 & 0.20\end{array}$ & $0.32 \quad 0.18$ & $\begin{array}{ll}0.60 & 0.08\end{array}$ & 0.68 & 0.34 \\
\hline $\begin{array}{l}\text { 90. Being afraid to in- } \\
\text { form the police about } \\
\text { experiencing sexual } \\
\text { violence oneself. }\end{array}$ & $-0.26-0.30$ & $-0.57-0.59$ & $-0.41-0.31$ & $0.08 \quad 0.14$ & 0.310 .05 & -0.47 & -0.03 \\
\hline $\begin{array}{l}\text { 91. To experience } \\
\text { sex discrimination } \\
\text { from government and } \\
\text { society. }\end{array}$ & $-0.75-0.11$ & $-0.91-0.23$ & $-0.84-0.22$ & 0.290 .13 & $0.04 \quad 0.08$ & -0.80 & 0.08 \\
\hline $\begin{array}{l}\text { 92. To feel that } \\
\text { government provides } \\
\text { material and / or legal } \\
\text { support for women. }\end{array}$ & $0.13 \quad 0.17$ & $\begin{array}{ll}0.40 & 0.20\end{array}$ & $0.62 \quad 0.19$ & -0.100 .03 & 0.100 .06 & 0.69 & 0.19 \\
\hline
\end{tabular}




\begin{tabular}{|c|c|c|c|c|c|c|}
\hline $\begin{array}{l}\text { 93. To believe that } \\
\text { government must } \\
\text { carry out policies that } \\
\text { support women. }\end{array}$ & $0.87 \quad 0.31$ & $\begin{array}{ll}0.80 & 0.28\end{array}$ & $\begin{array}{ll}0.89 & 0.24\end{array}$ & 0.540 .16 & $0.97 \quad 0.16$ & $1.04 \quad 0.35$ \\
\hline $\begin{array}{l}\text { 94. To show tolerance } \\
\text { of sexual minorities. }\end{array}$ & $\begin{array}{ll}0.13 & 0.25\end{array}$ & $0.22 \quad 0.18$ & $0.33 \quad 0.21$ & 0.120 .05 & $-0.36 \quad 0.09 \mid$ & $0.46 \quad 0.22$ \\
\hline 95. To be a lesbian. & $-1.20-0.60$ & $-1.25-0.44$ & $-0.82-0.15$ & $0.33 \quad 0.13$ & $-0.92-0.13$ & $-0.15-0.11$ \\
\hline $\begin{array}{l}\text { 96. To oppose capital } \\
\text { punishment. }\end{array}$ & 0.020 .05 & $0.06-0.02$ & $0.22 \quad 0.10$ & $\begin{array}{lll}-0.10 & 0.04\end{array}$ & $\mid \begin{array}{ll}-0.01 & 0.10\end{array}$ & $0.31 \quad 0.16$ \\
\hline $\begin{array}{l}\text { 97. To help one's son } \\
\text { to avoid enlistment. }\end{array}$ & $\begin{array}{ll}0.74 & 0.02\end{array} \mid$ & $0.65-0.02$ & $0.67 \quad 0.02$ & $0.08 \quad 0.05$ & $\left|\begin{array}{ll}0.89 & -0.02\end{array}\right|$ & $0.02 \quad 0.07$ \\
\hline $\begin{array}{l}\text { 98. To be patriotic re- } \\
\text { garding one's country. }\end{array}$ & $\begin{array}{ll}0.82 & 0.37\end{array}$ & $1.00 \quad 0.45$ & $\begin{array}{ll}0.86 & 0.42\end{array}$ & $-0.44-0.13$ & $\begin{array}{ll}0.76 & 0.26\end{array}$ & 1.180 .41 \\
\hline $\begin{array}{l}\text { 99. To abide by paci- } \\
\text { fistic beliefs. }\end{array}$ & 0.610 .06 & $\begin{array}{ll}0.67 & 0.09\end{array} \mid$ & $\begin{array}{ll}0.67 & 0.07\end{array}$ & $-0.11-0.02$ & $0.50 \quad 0.13$ & $0.59 \quad 0.10$ \\
\hline $\begin{array}{l}100 . \text { To believe in } \\
\text { men's superiority to } \\
\text { women. }\end{array}$ & $-0.68-0.36$ & $-0.78-0.24 \mid$ & $-0.50-0.17$ & $0.07-0.08$ & $\begin{array}{ll}0.01 & 0.08\end{array}$ & $-0.76-0.14$ \\
\hline
\end{tabular}

Attribution of acts. It would be interesting to analyze which acts (presented in the list) are attributed to certain roles, i.e. according to which positions a role received the maximal mark. This information is summarized in Table 3.2. Like Table 3.1, the answers of the Russian and American respondents in each cell follow one after another.

One has to bear in mind that the list did not include acts which were simultaneously attributed to two most opposite roles: $a$ despised woman and an ideal woman. However, if we compare the positions of a typical American woman and a typical Russian woman, the Russian respondents attributed 11 acts to them and the American respondents attributed 6 acts to them. It means that these positions are not opposite in public consciousness of the both countries.

There was only one question which demonstrated a significant negative correlation in both samples (-0.97): "To help a son to avoid military draft." This exception only confirms the fact that there is an opposite attitude to this issue in Russia and in the USA. From our point of view, this is caused by the compulsory military service in Russia. In the USA the compulsory military service can be only in the case of a war. Therefore, the majority of the American population in the 1996 viewes such a possibility theoretically and believed that, if an elected government has announced a 
war, citizens should be patriots and support the government. ${ }^{10}$ Any other military service is voluntary and all the marks for this position practically close to a neutral position. One may say that this question is not a construct of the American consciousness. The situation in Russia is different. The compulsory military service (with an unfavorable moral climate, non-statutory relations in the army, and so on) gives a lot of troubles for a family as soon as the age of a son is approaching to 18 years.

Thus, this analysis of attribution of various acts to opposite roles has shown that the American and Russian respondents share similar values and give similar estimations of various scenarios of a female behavior in society.

For example, the respondents of the two countries positively estimate a woman having higher education and a highly-qualified profession. A woman must pay attention to her appearance, health; she must go in for sports, hiking, be interested in art. The ideal family relations must be based on the equality of rights a husband and a wife.

From the point of view of the American and Russian respondent's a woman must not be a prostitute, she must not drink, smoke, take drugs, she should earn money herself and not be a burden for her parents, should not get married without love. A woman who prefers to live without children, an unfaithful wife, a woman who repudiates her (disabled) child or who does not want to help her disabled husband are estimated negatively by all the respondents.

One can say that there are common human values in both cultures; a woman is considered as a great force, she is able to realize this force and therefore is responsible for such a realization.

At the same time, we have discovered definite differences pertaining mainly to preferable life styles which are revealed in professional choice, in the choice of a partner in life (a husband).

From the point of view of the Russian respondents, happiness can be achieved mainly in a family. In their opinion, a woman is happy, if she has an opportunity to devote her life to her family, to be a housewife, to be involved in cooking, needlework, and so on.

On the contrary, the American respondents are sure that a woman can be happy in her professional realization. From their point of view, a woman can make the best career in medicine, in public relations, or in her own business.

10 Probably now the situation is changed in some subgroups in the US. 
Besides, in the American public consciousness a suffering person who cannot say OK in response to the question: "How are you?" is estimated negatively.

The graphic presentation makes the data analysis much easier. Of course, in the framework of one article it is impossible to draw graphs for all data contained in the table. However, it is possible to draw graphs for several semantic groups of answers. Let us consider items in the list which show the attitude of a woman to marriage, to the choice of a partner in life, to how to build family relations, to the professional choice. We were interested in how much one or another act or life scenario was acceptable for a respondent herself. We used the column corresponding to the myself item for the American and Russian respondents to draw graphs.

Among items of the list there were statements which shown marriage preferences of women in Russia and in the USA. The choice of a husband, when we talk not about a particular man but about his social position which includes his profession, material status, ethnic belonging, and so on, is closely connected with the choice of a preferable lifestyle. The choice of a husband is a personal choice of life values and norms. Thus, the analysis of marriage preferences allows us to reveal the system of value orientations and it is one of most popular ways of the crosscultural studies (Arutyunyan, Drobizheva, \& Susokolov, 1998).

The marriage preferences of Russian and American women are illustrated by a histogram in Figure 3.1. To draw the histogram, we used the appropriate items of the list in the column corresponding to the myself role from Table 3.2.

The histogram shows that Russian women mostly prefer to marry a man of a higher social status (0.63), this preference is a little lower in case of being married to an "ordinary," nonintellectual man whose chief interest is in his home and living a comfortable life and who is skilled in handling domestic tasks (0.44). Such scenarios reveal a desire to find safety, stability, and guaranteed life standards in the marriage either at the expense of the high husband's status or due to his ability to settle all life problems. The Russian respondents consider the second scenario as the most typical in Russia and the first scenario as the most typical in the USA. The American respondents have also estimated marriage with a man of higher social status positively though a bit less (0.24). Such a marriage allows an American woman (especially non-working) to take higher social position and this is widely spread. For the most part the status of a married woman in the 


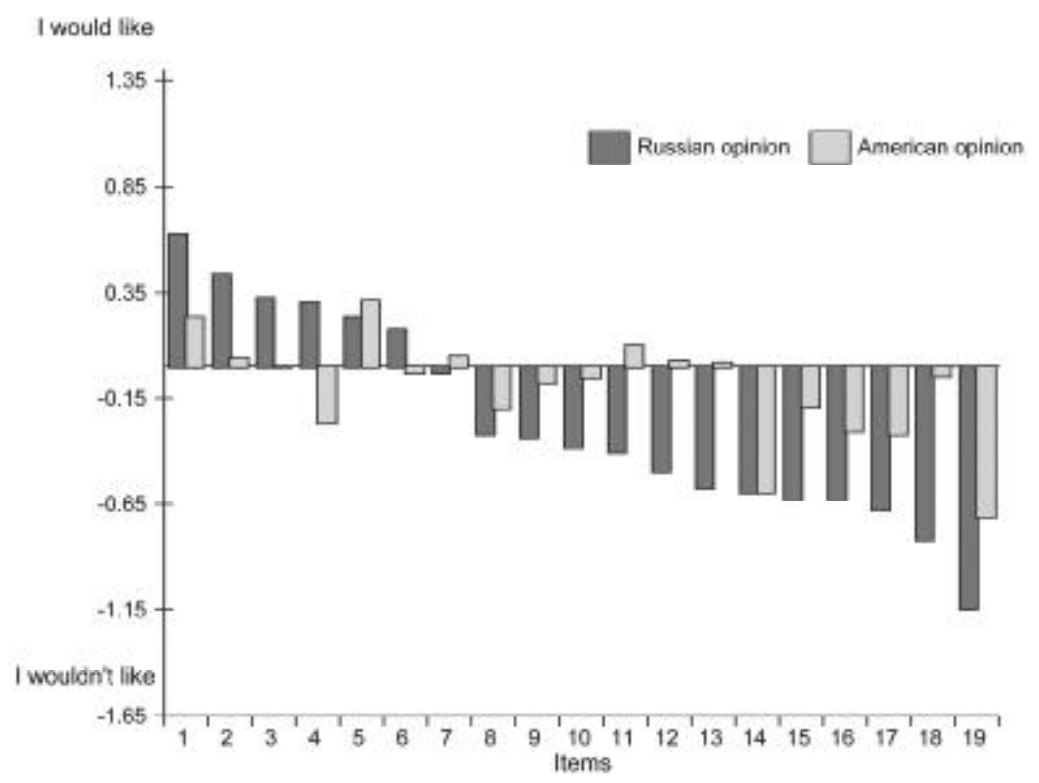

Figure 3.1. Marriage preferences of Russian and American women. Items: 1. To marry a man of higher social status than her own. 2. To marry an "ordinary," nonintellectual man whose chief interest is in his home and living a comfortable life and who is skilled in handling domestic tasks. 3. To marry a man whose ethnicity differs from ones' own. 4. To marry a beloved man who has a very low income and no prospects for increasing it. 5. To marry a businessman. 6 . To marry a man who devotes his life to science. 7. To marry an artist (musician, poet, artist). 8. To marry a foreigner and live abroad. 9 . To marry a military man. 10. To marry a politician. 11. To marry a blue collar worker. 12 . To be kept by a well-off man. 13. To marry a celebrity (in sports, movies). 14. To marry without love, marrying for money. 15. To marry a farmer. 16. To marry a man whose race differs from her own. 17. To regard living alone as better than getting married. 18. To marry a deeply religious man. 19 . To marry a member of a criminal group.

USA is determined by the status (position, profession) of her husband. In such a situation the possibility to build family relations based on the equal rights is substantially decreased. For the American respondents the most preferable husband is a businessman (0.32). In a stable society when it is possible to make a business without a great risk, the image of a busi- 
nessman is rather close to the image of the master of the house. However, the first is more clear and understandable and therefore American women give preference to businessmen. In Russia to become a businessman's wife in the middle of the 90s meant impossibility to have a peaceful guaranteed life, conscious acceptance of situations when not only her husband takes a risk but she herself and her children as well.

The Russian respondents estimate a possibility to live with a man as a family without an official marriage registration is rather high. In the Soviet times so called "civil marriages" were not approved. Nowadays in Russia there are no moral and ideological restrictions. For many Russian women civil marriage is sufficiently acceptable, since there is no tradition to conclude marriage contracts, a few people possess substantial property which is necessary to fix legally, and lonely mothers get some economical benefits of being officially not married which makes up-bringing of children easier.

American women can also live with a man without not getting officially married; they also admit a possibility to live at the expense of a rich man (for myself 0.03 , for ideal 0.04 , for a happy woman 0.20 ). Note, that the Russian respondents strongly disapprove this (for myself $-0.49, m y$ ideal -0.50, a happy woman -0.08). However, neither this sort of relations, nor relations of "boyfriends," "girlfriends" (which are widely spread not only among young people but also among older people) are called marriages: there are no legal, economical or any other commitments between partners (probably only moral commitments). A couple can be split at any time. That is why the American respondents negatively estimate civil marriages. If a man and a woman want to live as a family, to have a common home, and to have children, they register their relations legally, sign a marriage contract, accept economical responsibilities, and so on. A civil marriage can be admitted in the case when one of the two partners is already married, but for some reasons this marriage can not be dissolved.

It is worth mentioning that the Russian respondents (most of them lived in Moscow and were rather free from national prejudices) positively view marriages with men of another ethnic group. ${ }^{11}$ The American respondents consider this item neutrally. The problem of interrelations between representatives of various ethnic groups is less important than interrelations between representatives of different races, confessions, countries.

11 The situation in the end of 90 s. Now opinion about this question probably would be different. 
To marry a man of another race is possible only due to great love and the maximal mark for this item was given to a happy woman (because it means that she has this great love and precisely this makes her happy). The Russian respondents rejected such a possibility, just because there are no many representatives of different races in our country.

As for marriages with foreigners, the American respondents explain this act by love and therefore connect it with happiness. They think that to marry a foreigner and move to his country is possible only because of great and happy love. Such an act was estimated by the maximal mark (0.34) for a happy woman. The American respondents are sure that such a situation is rather typical for any country - there are no borders for love. A despised woman has got neutral mark (practically) for this item (0.03). "Who would marry her if she is despised?" Estimating the position myself, the respondents have answered negatively on the average $(-0.20)$. Probably it is difficult to answer this question theoretically. Every woman thinks that she is unlikely to end up in such a situation until she meets a foreigner, falls in love with him and is ready to move to another country. The American respondents do not disapprove a woman, if she would act in this way.

The Russian respondents have estimated this item ambivalently. The item has got the maximal mark for a happy and despised woman simultaneously. (The American respondents have similar ambivalent reaction towards the item "to marry a man of another race.") Many Russian women look upon marriage with a foreigner as the only possible way to find themselves in the "capitalist paradise," to get rid of problems and difficulties of the Russian reality. They dream about a prince on a white Mercedes who could make a woman happy. In Russia there are plenty marriage offices looking for husbands from the USA, Canada, Europe, Japan. ${ }^{12}$ On the other hand, the image of a woman who is going to marry a foreigner is closely correlated in the public consciousness with the image of an expen-

12 There is very popular song of one Russian female musical pop group Kombinaciya: American boy, American joy

American boy for always time

American boy, I will go with you

I will go with you, Moscow good buy!

I will be crying and laughing

When I sit in Mercedes

I will swim in luxury

Come sooner to take me, I am here. 
sive prostitute who served well-paying foreigners ("an inter-girl"), which is strongly disapproved in Russia. (See item 23 in Table 3.2.) The Russian estimation of the myself position is similar to the American one (-0.32). The reason may be that it is difficult for the Russian respondents to imagine such a situation hypothetically. One does not want to act as a despised woman, but in the same time does not believe that can find happiness in such a marriage.

An important difference between the Russian and American respondents concerns marriages with a man having low income. As for themselves, the Russian respondents estimate this possibility positively. This fact has Soviet roots: personal features of a man were much more important than his income and in the USSR the former sometimes contradicted the latter (Shlapentokh, 1992). Nevertheless, the roles of an ideal and a happy woman have positive yet lower marks for this item. It means that there is a tendency of changing Russian value orientations towards "west" value orientations. "If you are so clever (nice, kind, and so on), why are you so poor?" From the Russian point of view, such a marriage choice is not peculiar to an American woman (this is in agreement with answers given by the American respondents). However, the Russian respondents do not approve a woman who takes into account only material side, a despised woman acts like this.

Let us compare the ratings given to items "to marry a scientist" or "a man of art." Although averaged marks offered by the Russian respondents to these items are different, these two choices are estimated positively. From the Russian point of view, to marry a scientist is prestigious in the whole world, and it is not by chance that a typical American woman (as a realization of success) position has got the maximal mark for this item. The American respondents have ranked these items in a similar way. Concerning the myself position, the possibility to marry a man of art is estimated slightly negatively by the Russian respondents $(-0.03)$ and slightly positively by the American respondents $(0.05)$, while the possibility to marry a scientist is estimated positively by the Russian respondents (0.18) and slightly negatively by the American respondents $(-0.03)$. This different approach is explained by different situations in two countries. In Russia the scientists' community is traditionally more democratic than the art community which is closed for strangers. On the contrary, in the USA the scientist community is more refined and isolated than the art world. There are a lot of musicians, artists, writes, 
etc. in this country and therefore the art community is more open. It is important to say that the positive marks given by the Russian respondents for the possibility to marry a man, who devoted his life to science, show that science as a lifestyle is still valuable in this country. To be a scientist's wife is still prestigious and honorable in spite of all talks about a disastrous situation in the Russian science.

An American woman, if she wants, will devote her life to science and her husband could be a businessman or a worker. In our country the perspective to marry a worker is estimated negatively, since this occupation is neither prestigious nor well-paid. The social status of a worker in the USA differs significantly form the social status of a worker in Russia. In the USA a qualified worker is well paid and for this reason his life is stable and interesting. As a rule, a US worker has fixed working hours and therefore has enough free time for his family in contrast to scientists who have much less free time.

The positive attitude of the American respondents and the negative attitude of the Russian respondents to the possibility to marry a "star" can be also explained by the fact that this community is more open in the USA than in Russia.

As for other questions, the American and Russian respondents gave similar answers. They do not see themselves as a wife of a criminal, a deeply religious man, a farmer, a politician, a military man. They do not want to get married without love and they do not want to live without a husband. It should be noted that the Russian respondents are more explicit in expressing their opinion than the American respondents. The length of "the American columns" is significantly shorter.

To have a university education or to have a profession demanding high-level skills are estimated highly by the American and Russian respondents while jobs requiring low-level skills are estimated negatively by them. And it should be pointed out again that the American respondents are less explicit in their estimations of preferences and rejections. Besides, a high salary is the main motivation for an American woman to have a high-level skill (in the USA the high salary is correlated strongly with education). For a Russian woman her self-realization and the increase in her self-estimation are much more important than earned money.

A gap in the opinions of jobs in a public institution is apparent among the Russian and American respondents. The Russian respondents highly estimated the possibility to work in a public institution, because such a 
job means some stability, a salary paid regularly (though it is not high sometimes) which is guaranteed by the state. In spite of numerous "defaults," Russian women still trust the state. It is important for women to get various benefits granted by the state (sick-leave certificates, subsidies for children, and so on). All these arguments are not important for an American woman. While working in private firms, they are also protected by law. Since one can do any job in a public enterprise (from the boss to a cleaner), the American respondents have estimated the possibility to work there neutrally.

In addition, Russian private companies prefer to hire men on important positions. The fact that a woman can easier be hired by a public institution than by a private company, may have affected the answers of the Russian respondents.

The respondents of both countries consider the perspectives to devote themselves to their families being housewives or to make a career as possible life scenarios. However, one should observe that the American columns corresponding to these items are a bit higher than the Russian ones. Probably this is because Russian women, as a rule, have to do everything themselves while American women are either housewives or if they make career there are helping hands in the house. It is important that they always make their own choice and therefore their estimations are more positive.

Office jobs are also attractive for the Russian and American respondents. But American women are more accustomed to this sphere, while Russian women are more accustomed to the education sphere.

The possibility to be involved in science is preferable for Russian women, while American women rather reject this possibility. As in the case with marriage preferences, in Russia scientific work is very attractive and it is easier to achieve.

The difference in estimating the possibility to have an own business or to be in charge of a company manifests greater professional and social activity of American women as compared with Russians. Russian women tend to see themselves as assistants than as independent leaders in work and in the society.

Interestingly enough, the Russian respondents have a negative attitude to traditionally male professions, while the American respondents view them positively. Such a difference is caused by widely spread prestigious male professions among American women. They highly estimate the possibility to work in the Army, Navy, secret services where it is re- 


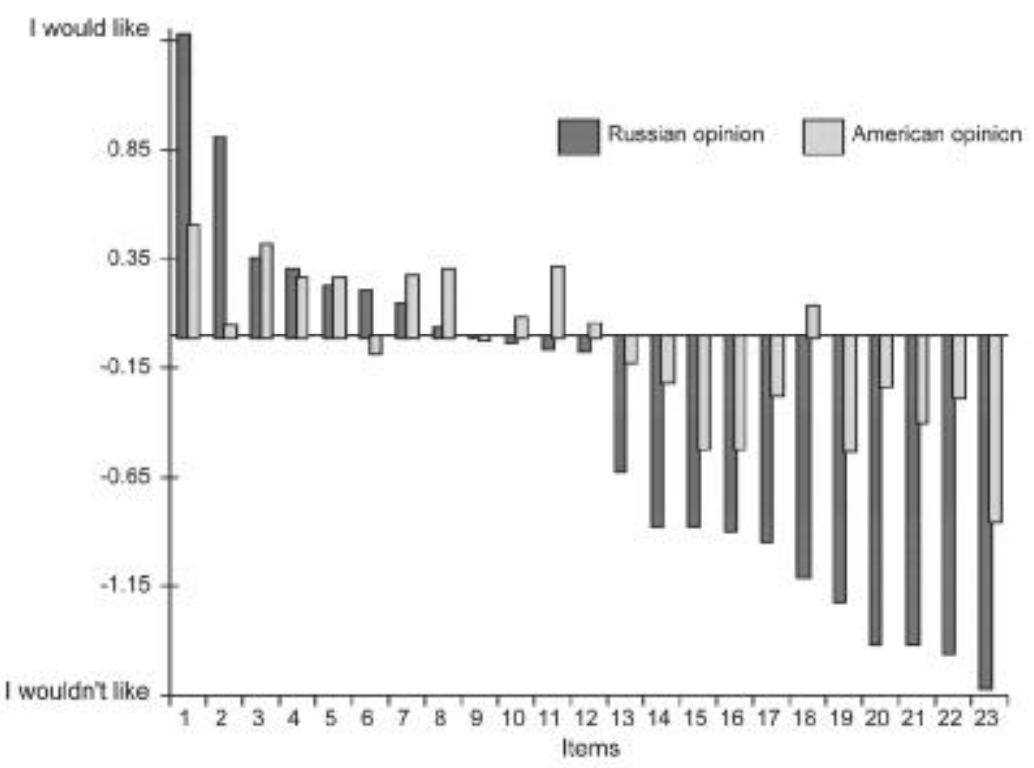

Figure 3.2. Professional preferences of Russian and American women. Items:

1. To have higher education and / or a profession that requires highly developed skills. 2 . To work in the civil service. 3 . To devote one's life to a professional career. 4. To work in education (tutor, teacher etc.). 5. To be a businesswoman. 6. To work in Science. 7. To devote one's life to a family, be a housewife. 8. To have one's own business. 9. To work in the mass media (journalist, editor, broadcaster). 10. To practice medicine (doctors, nurses). 11. To be a leader (of an enterprise, organization, agency). 12. To work in the arts (actress, painter, writer etc.). 13. To work as a salesperson or in a service industry (hairdressers, waitresses etc.). 14. To work in agriculture. 15. To work in a factory or mill. 16. To work in an unskilled, low-income job. 17. To become a model and / or to take part in beauty competitions. 18. To have a traditionally male profession. 19. To become a professional sportsperson. 20. To live without working and rely on help from the parents. 21. To become a professional politician. 22. To devote one's life to a religious order. 23. To be a prostitute.

quired to have high skills and good physical form. Due to the strong influence of feminism in the USA, a woman has equal rights with a man and this provides American women with an opportunity to compete successfully with men for prestigious jobs. In Russia women also take 
traditionally male jobs, but only those which do not require high skills and which are therefore low-paid and sometimes harmful for health (for example, loaders, builders, and so on). That is why the Russian respondents negatively estimate male jobs accessible for them.

Generally, the possibility to become a professional sportswoman or a model is estimated rather positively in the both samples, but since among our respondents there were not representatives of these professions (and these spheres are quite closed) in the myself role, these professions have been estimated negatively. The most negative attitude for both Russians and Americans was to prostitution.

In addition to social public roles which are realized in marriages and careers, each woman is a daughter, wife, and mother. These roles are mainly determined by personal features. Nevertheless, there is a limited set of scenarios for these roles which reveal some cultural stereotypes.

The Russian and the American respondents have given their maximal marks to family relations based on equal rights. The possibility to be the head of the family has been estimated neutrally. However, American women see themselves in this role more often than Russian women who prefer to be just assistants (as in the professional sphere). Perhaps, in their view, the leader of the family is supposed to ensure the family income while American women are more consistent and prefer to solve financial problems in the principle of equal rights.

The infidelity has been estimated negatively by the respondents of two countries. But the American respondents can forgive their husbands more easily and they are more severe concerning to themselves.

The American respondents are more responsible and strict concerning marriage. They admit a possibility of divorce only due to alcoholism, unlike the Russian respondents, who rather often divorce an unloved husband, even if they have children. The Russian respondents consider this possibility sufficiently real for all roles apart from the role of a despised woman. Such a possibility has been estimated negatively for this role, but almost equal to neutral (-0.06). The Russian respondents have ascribed the maximal possibility of divorce an unloved husband, even when they have children, to a typical American woman (0.74) and to an ideal woman (0.64). On the average the Russian respondents have estimated the possibility of divorce an unloved husband (if they have children) positively (0.57) to myself and much lower (0.19) to a typical Russian woman positions. On the contrary, the American respondents do not approve such 


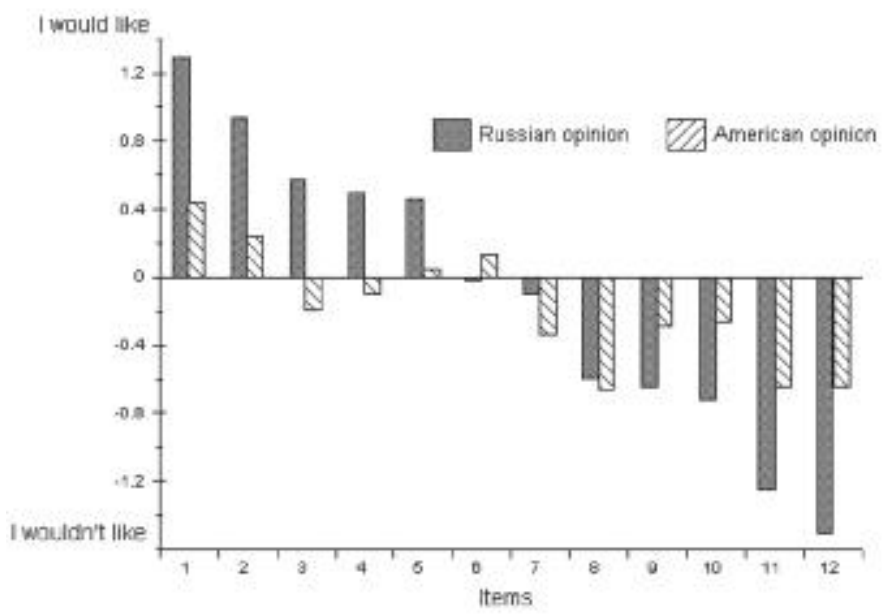

Figure 3.3. Family relations preferences of Russian and American women. Items: 1. To build up family relationships according to the principle of equal rights. 2 . To divorce the husband because he is an alcoholic. 3. To divorce an unloved husband while having children. 4 . To think that financial security of one's family is the husband's responsibility. 5 . To have savings separate from a spouse. 6 . To be the head of the family. 7. To divorce the husband after he is diagnosed to have AIDS. 8 . To be unfaithful to the husband. 9. To tolerate the possibility of the husband's infidelity. 10. To divorce the husband who has become a disabled. 11 . To remain married when one is experiencing violence from the husband. 12. To remain married when one's daughter is experiencing violence from her stepfather, the current husband.

an act and they have estimated the possibility of committing such an action negatively $(-0.17)$ to an ideal and more severe $(-0.20)$ to myself. They have ranked third a typical Russian woman position (-0.09), and to a typical American woman position they have given a mark of (0.13). This is according to negative connotations concerning the ideal position. Thus, from the Russian point of view, the act discussed above is characteristic of the American culture (with feminism and female independence) to a greater extent than to the Russian one, but, at the same time, this serves as a sort of an ideal example. The American auto-stereotype (i.e. the mark given by the American respondents to a typical American woman) coincides with the Russian hetero-stereotype (i.e. the mark given 
by the Russian respondents to a typical American woman). The American respondents look upon the situation when an American woman divorces an unloved husband (even if they have children) as quite possible. However, in contrast to the Russian respondents, they do not approve such an act. Therefore the American respondents have estimated a typical Russian woman positively because from their opinion she can commit such an action to a lesser degree than an American woman.

Violence with respect to children or to wives has been rejected in both countries.

As for the relations with parents, the difference revealed in item 60 "that parents have should not interfere with their children's private lives" seems to be the most striking. The Russian respondents have given positive answers to this question (in the myself role they have given a mark of 0.76). Unlike them, the American respondents do not support this statement (the corresponding mark in the American excerpt is 0.1) regardless of the American tradition to move out of parents' home after graduating from high school, the links between children and their parents remain close. It is not by chance that in the USA there was an advertisement featuring mobile phones that called upon parents to buy these mobile phones for them and their children so that to keep in touch at any time and at any place. In the American universities and colleges there is a tradition to invite parents to take part in celebrations of the beginning and the end of an academic year. Administrations of educational enterprises invite parents to become members of various counsels and in this way to participate in life of their children.

Moreover, we have found out different attitudes to giving a birth and up-bringing a child out of wedlock. The American respondents are sure that it is much better to raise a child in an officially registered family. They have estimated the possibility to have an out of wedlock child negatively (in the myself role they have given -0.28 , while the Russian respondents have given 0.2). It means that in the American consciousness the main goal of creating a family is up-bringing children. Therefore, the American respondents have estimated the divorce (with children in a family) negatively in contrast to positive estimations given by the Russian respondents (see above).

The factor analysis has been carried out in order to reduce the initial number of various acts (situations) and combine situations strongly correlating with each other in some groups. Similarity of situations has 
been estimated on the grounds of similarity of marks ascribed to various roles in these situations. The revealed factors reflect profound bases of classification which present in the consciousness of our respondents. In the geometrical presentation of the obtained results these factors are the axes of the $n$-dimensional semantic space, where $n$ is the number of independent factors. The analysis of the factor marks allows us to interpret the factors more accurately.

The analysis of the factor processing each of the four matrices (male and female for Russians and Americans) has shown that the factor structures obtained for Russian men and Russian women are close to each other if compared with the similar structures obtained for American men and American women. The difference between the factor structures determinable for the same gender is much greater than between the factor structures determinable for the same country.

Like the experiment 2, this result again supports our idea that people's opinions about norms and codes of the female behavior are much more determined by a culture than by a gender. In other words, stereotypes and requirements to a female role have much more in common among representatives of one culture (men and women) than stereotypes of women belonging to different cultures (if we compare them); the same is relevant to the male samples.

Table 3.2 presents the raw data. The matrices of ranked estimations obtained by using these marks can be unified and data from all of them can be compared more correctly and adequately. This allowed us to exclude differences due to which our respondents have given more neutral estimations peculiar to American women as compared to Russian women and to Russian men as compared to American men as well.

As a result of the factor analysis we singled out three most important factors.

The first factor explains $39 \%$ of the total variance. Its positive pole is formed by the following items:

50. To build up family relationships on the principle of equal $\quad 0.90$ rights.

3. To have higher education and / or a profession that requires 0.86 highly developed skills.

80 . To give attention to one's appearance and health. $\quad 0.83$

81 . To engage in sports and / or to travel.

84. To devote free time to creative works, art. 0.73 
The negative pole of the first factor is formed by the items:

57. To start a love affair with someone from one's workplace. $\quad-0.98$

74. To use narcotics, tranquilizers etc. -0.98

39. To get married without love, marrying for money. $\quad-0.97$

56. To be unfaithful to the husband.

44. To divorce the husband who has become a disabled. $\quad-0.97$

72. To smoke cigarettes. $\quad-0.97$

45. To divorce the husband after he is diagnosed to have AIDS. -0.97

62. Not to have children because one thinks it is better to live $\quad-0.97$ without them.

32. To marry a member of a criminal group. -0.97

76. To wish that one could change one's sex from time to time. -0.96

23. To be a prostitute. $\quad-0.96$

18. To live without working relying on help from one's parents. -0.95

64. To leave a disabled baby to the care of an agency. -0.95

63. To leave a baby in the maternity hospital, if one lacks $\quad-0.95$

financial support from somebody.

42. To be kept by a well-off man.

75. To commit suicide. $\quad-0.95$

61. To marry early in order to be free of parental supervision $\quad-0.93$ and control.

48. To remain married when one is experiencing violence $\quad-0.93$

from the husband.

49. To remain married when one's daughter is experiencing $\quad-0.93$

violence from her stepfather, the current husband.

4. To work in an unskilled, low-income job. -0.91

67. To give children to the former husband after divorcing. $\quad-0.90$

95. To be a lesbian. $\quad-0.89$

73. To use alcoholic beverages.

46. To regard living alone as better than getting married. $\quad-0.88$

59. To agree in advance with one's parents' choice of a fiancé. $\quad-0.88$

54. To tolerate the possibility of the husband's infidelity. $\quad-0.87$

9. To work in a factory or mill.

91. To experience sex discrimination from government and $\quad-0.79$ society. 
The semantic analysis of the items forming the both poles of the first factor allows us to interpret it as an evaluation: Positive evaluation $\leftrightarrow$ Negative evaluation (or Acceptance $\leftrightarrow$ Rejection).

The second and third factor responsible for $26.1 \%$ and $12.2 \%$ of the total variance, correspondingly, have one pole for each.

The positive pole of the second factor is formed by the items:

85. To take part in public and political activities.

16. To work in the mass media (journalist, editor, broad- $\quad 0.92$ caster).

87. To be a member of a women's organization.

0.91

36. To marry a man whose nationality differs from her own. $\quad 0.88$

13. To be a leader (of an enterprise, organization, agency). $\quad 0.88$

25. To marry an artist (musician, poet, artist). 0.88

14. To have her own business. $\quad 0.87$

31. To marry a celebrity (in sports, movies). $\quad 0.87$

26. To marry a businessman. $\quad 0.87$

68. To adopt and raise someone else's baby. $\quad 0.87$

11. To be a businesswoman. $\quad 0.86$

92. To feel that government provides material and / or legal $\quad 0.86$ support for women.

86. To carry out charitable actions in public-social organiza- $\quad 0.83$

tions (asylums, shelters, etc.).

40. To marry a man of higher social status than one's own. $\quad 0.81$

22. To become a model and / or to take part in beauty compe- $\quad 0.80$ titions.

98. To be patriotic regarding her country. $\quad 0.80$

2. To devote her life to a professional career. $\quad 0.79$

17. To work in the arts (actress, painter, writer, etc.). 0.78

51 . To be the head of the family.

12. To have a traditionally male profession. $\quad 0.77$

21. To become a professional sportsperson. $\quad 0.75$

7. To work in science. $\quad 0.73$

52. To have savings separate from one's spouse. $\quad 0.72$

34 . To marry a deeply religious man. $\quad 0.71$

8 . To practice medicine (doctors, nurses). $\quad 0.70$

27. To marry a politician. $\quad 0.70$ 
The semantic analysis of these items allows us to interpret the second factor as Social activity.

The positive pole of the third factor is formed by the items:

82. To be fond of needlework (sewing, embroidery, knitting). $\quad 0.88$

24. To marry an "ordinary," nonintellectual man whose chief 0.88

interest is in his home and living a comfortable life and who is

skilled in handling domestic tasks.

1. To devote her life to a family, be a housewife.

53. To think that financial security of a family is the husband's 0.76 responsibility.

58. To guide her own behavior by the traditions and moral

norms accepted by her society. activity.

We have interpreted the third factor as Home orientation or In family

The Figures below presents the projections of the factor space together with semantic content of the extracted dimensions. The coordinates of the points for each role position of Russian and American men and women (on the whole there are 24 points) correspond to factor scores obtained by these positions after the factor analysis. As it can be easily seen from these figures, the estimations of the most role positions given by men and women of the same country are close to each other. In addition, the points corresponding to the same role positions which were estimated by respondents of the both countries form rather compact clusters. This indicates that there are similar stereotypes concerning the female behavior in the both cultures.

While analyzing the distribution of positions according to the first factor of evaluation, we notice that the American respondents have more positive attitudes to themselves than the Russian respondents do. Besides, the ideal for the American respondents is closer to a real image of myself (or to a well-known woman, who received the maximal mark in accordance to this factor). It is worth noticing that although the American respondents are more inclined to feel happy themselves (as has been said above), the image of a happy woman is less accepted (evaluated positively) by them as compared with the Russian respondents. Perhaps they think that to be happy in life is a norm while the absence of happiness is a negative quality. As it has been expected in both countries the respondents reject the role of a despised woman and it is worth to notice that the 


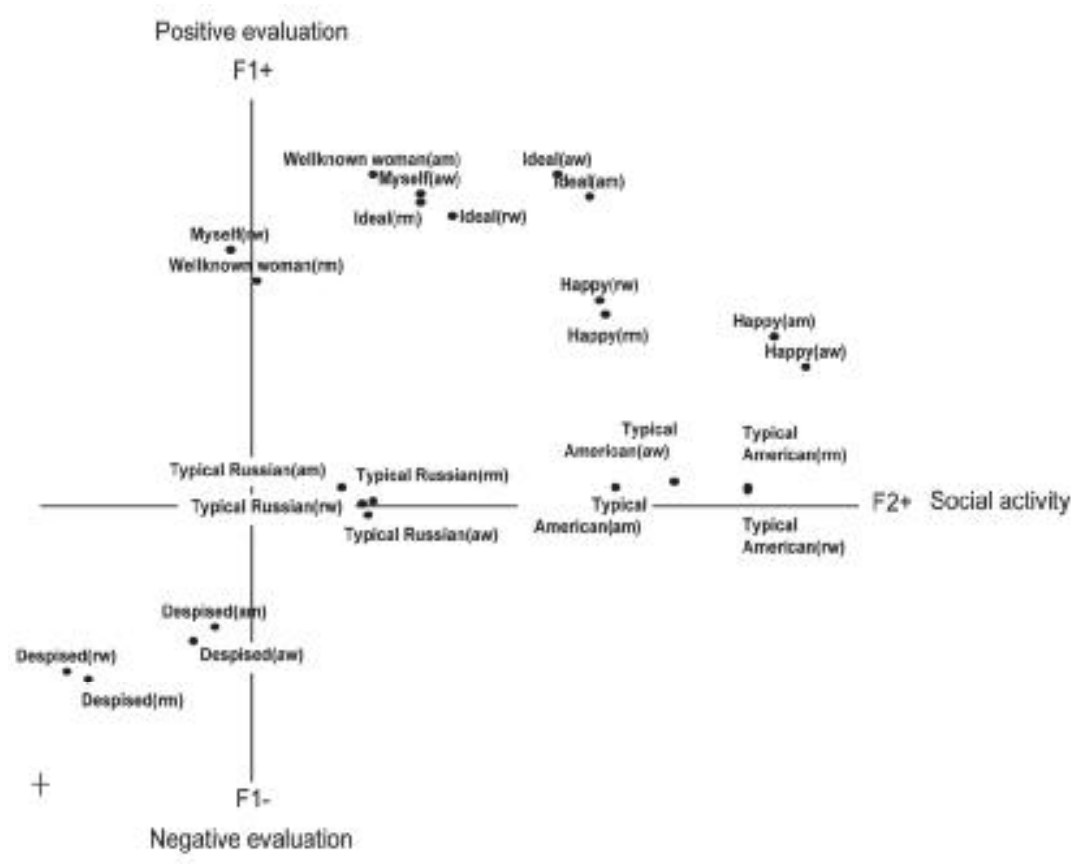

Figure 3.4. Images of Russian and American women from Russian and American points of view (F1, F2)

rw - point of view of Russian Women, rm - point of view of Russian Men,

aw - point of view of American Women, am - point of view of Russian Men

Russian respondents reject this role more strongly than the American ones. A typical woman is estimated neutrally.

In spite of seeming contradiction of the second and third factors emancipation i.e. orientation on the public activity and society, and being patriarchal, i.e. oriented on the family and home - the result of this research shows that these two types of the life activity are sufficiently independent in public opinion of the both countries. The correlation coefficient between these factors is equal to zero (to be more exact it is equal to 0.005$)$. In the USA and Russia it is typical for a woman to combine home and job, family and public activity in her life, and being successful in both aspects which make her happy. A despised woman is not success- 


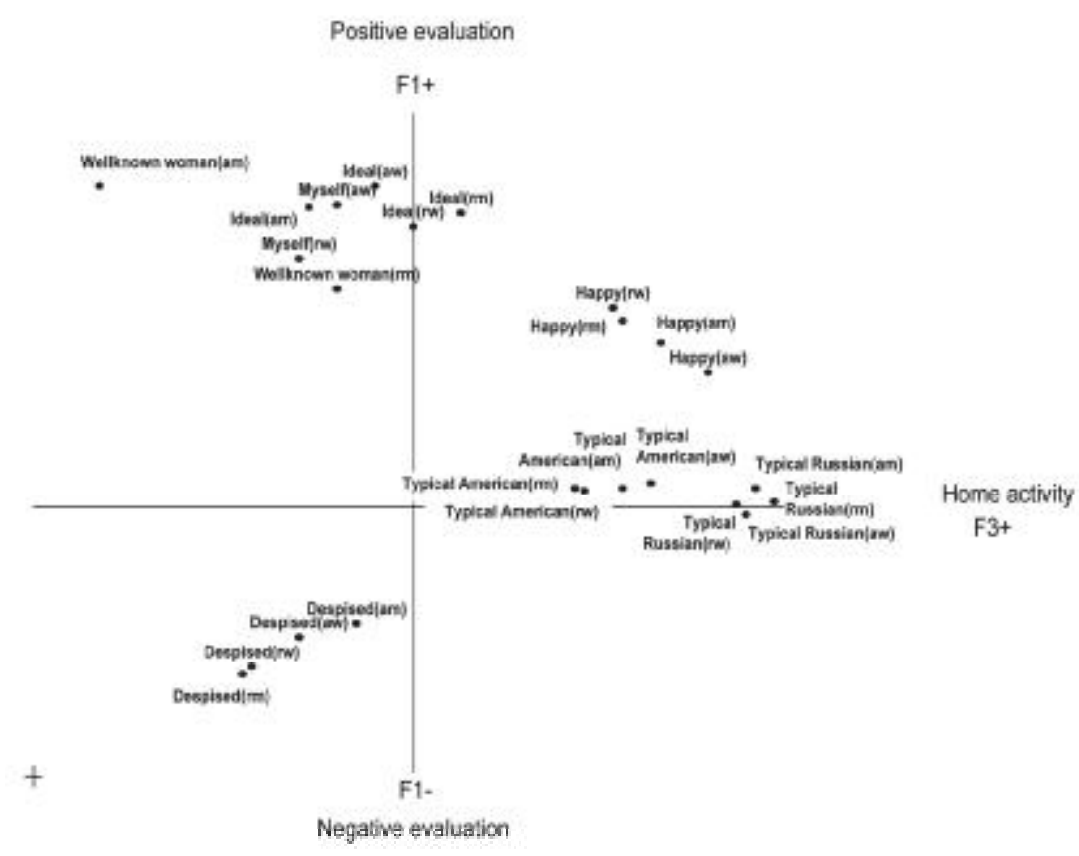

Figure 3.5. Images of Russian and American women from Russian and American point of view (F1, F3)

rw - point of view of Russian Women, rm - point of view of Russian Men, aw - point of view of American Women, am - point of view of Russian Men

ful in these aspects. A typical American woman is estimated by all the respondents as primarily oriented on public activity (such an estimation was given mainly by the Russian respondents); while a typical Russian woman is primarily oriented on her family life. Notice that the American respondents ascribe the priority of the social activity to their ideal, i.e. being oriented on public activity is estimated positively. However, an ideal woman should not be involved in public activity too much.

The similarities and differences in estimations of the female behavior and in life scenarios which were fixed in this study reveal more profound similarities and differences of values orientations and purposes of these two cultures. In spite of the great differences in the lifestyle of Americans 
and Russians, there are nevertheless general features in the development of the two countries. The main feature is the similarity of geo-political space, self-perception as citizens of superpowers and their predestination in the world scale. As soon as the iron curtain which divided us for such a long time was destroyed, Americans and Russians began studying each other with mutual interest. They began solving state and political problems, carrying out joined scientific investigations, organizing busyness, realizing cultural projects, and just simply communicating. It has turned out that we easily find understanding, we have many common interests. For example, our research has shown that there are no possible acts and life scenarios which we estimate differently. We have the same idea about what is good and what is bad.

Nevertheless, it is naïve to assume that the two cultures having absolutely different historical, political, and economical background are identical. We speak different languages; the USA is a country of immigrants while Russia has century-old traditions, ancestors. The Russian mentality is determined substantially by Orthodoxy while the American by Protestantism. Sacrifices, sufferings are highly appreciated in the Russian tradition, while in the American tradition the most appreciated are deeds which bring a result.

However, we view our future co-existence hopefully and optimistically. There is no doubt that the co-development in our common home on the Earth is a mutually profitable process.

\section{References}

Aivazova, S. (1998). Russkie žensiny v labirinte ravnopraviâ [Russian Women in the Labyrinth of Equal Rights]. Moscow: RIK Rusanova. Progress.

Argyle, M. (1990). Psihologiâ sčast'â [The Psychology of Happiness]. Moscow:

Arutyunyan, Yu.V., Drobizheva, L.M., \& Susokolov, A.A. (1998). Ėtnosociologiâ [Ethnosociology]. Moscow: Aspekt-Press.

Baiburin, A.K., \& Kon, I.S. (Eds.). (1991). Ėtničeskie stereotipy mužskogo i ženskogo povedeniâ [Ethnic Stereotypes of Men and Women Behavior]. Saint Petersburg: Nauka.

Bakhtin, M.M. (1979). Estetika slovesnogo tvorčestva [Esthetic of Verbal Creativity]. Moscow: Iskusstvo.

Basow, S.A. (1992). Gender Stereotypes and Roles (3d ed.). Pacific Grove, CA: Brooks/Cole Publishing. 
Beere, C.A. (1990). Gender Roles: A Handbook of Tests and Measures. New York: Greenwood Press.

Beere, C.A., King, D.W., Beere, D.B., \& King, L.A. (1984). The Sex-Role Egalitarianism Scale: A Measure of Attitudes toward Equality between the Sexes. Sex Roles, 10, 563-576.

Bhushan, L.I. (1981). Women's Social Freedom Scale. Psychologia, 24, 239-243.

Bodalev, A.A. (1983). Ličnost' i obŝsenie [Personality and Communication]. Moscow: Pedagogika.

Bryant, K. (2003). What's the problem with "gender identity disorder"? Sexuality, gender, and critical blind spots. Paper presented at the annual meeting of the American Sociological Association, Atlanta, GA.

Chia, R., Allred, L., \& Jerzak, P. (1997). Attitudes toward Women in Taiwan and China: Current Status, Problems, and Suggestions for Future Research. Psychology of Women Quarterly, 21, 137-150.

Costanzo, M., \& Oskamp, S. (Eds.). (1993). Gender Issues in Contemporary Society: Claremont Symposium on Applied Social Psychology. Newbury Park, CA: Sage.

Deaux, K., \& Lewis, L.L. (1984). The Structure of Gender Stereotypes: Interrelationships among Components and Gender Label. Journal of Personality and Social Psychology, 46, 991-1004.

Dzhidaryan, I.A. (1997). Predstavlenie o sčast'e v russkom mentalitete [Happiness Representation in Russian Mentality]. Psihologičeskij žurnal, 18 (3), 13-25.

Fransella, F., \& Bannister, D. (1977). A Manual for Repertory Grid Technique. New York: Academic Press.

Gapova, E.I., \& Usmanova, A.R. (Eds.). (2000). Antologiâ gendernoj teorii [Antology of the Gender Theory]. Minsk: Propilei.

Hinshaw, L., \& Forbes, G. (1993). Attitudes toward Women and Approaches to Conflict Resolution in College Students in Spain and the United States. Journal of Social Psychology, 133, 865-867.

Hofstede, G. (1991). Cultures and Organizations. London: McGraw-Hill.

Kalin, R., Heusser, C., \& Edwards, J. (1982). Cross-National Equivalence of a SexRole Ideology Scale. Journal of Social Psychology, 116, 141-142.

Kelly, G.A. (1955). The Psychology of Personal Constructs. New York: Norton.

Klimenkova, T.A. (1996). Žensina kak fenomen kul'tury. Vzglâd iz Rossii [Woman as a Phenomenon of Culture: View from Russia]. Moscow: Preobraženie.

Kon, I.S. (1978). Otkrytie Â [Discovering of Self]. Moscow: Politizdat.

Kostikova, I.V. (Ed.). (2005). Vvedenie v gendernye issledovaniâ [Introduction to Gender Study]. Moscow: Aspekt-Press.

Leontiev, A.N. (1978). Activity, Consciousness, and Personality. Englewood Cliffs, NJ: Prentice Hall. http://www.marxists.org/archive/leontev/ 
Levant, R., Cuthbert, A., Sellers, A., Matveev, A., Mitina, O., Sokolovsky, M., \& Heesacker, M. (2003). Masculinity Ideology Among Young Russian and American Men and Women and Its Relationship to Unhealthy Life Style Habits Among Young Russian Men. Psychology of Men \& Masculinity, 4 (1).

Levine, R., \& West, L. (1979). Attitudes toward Women in the United States and Brazil. Journal of Social Psychology, 108, 265-266.

Loo, R., \& Thorpe, K. (2000). Confirmatory Factor Analyses of the Full and Short Versions of the Marlowe-Crowne Social Desirability Scale. Journal of Social Psychology, 140, 628-635.

Lott, B. (1994). Women's Lives. Themes and Variations in Gender Learning (2nd ed.). Pacific Grove, CA: Brooks/Cole Publishing.

McHugh, M.C., \& Frieze, I.H. (1997). The Measurement of Gender-Role Attitudes: A Review and Commentary. Psychology of Women Quarterly, 21, 1-16.

Mitina, O.V. (1999). Ženskoe gendernoe povedenie v social'nom i krosskul'turnom aspektah [Women's Gender Behavior in Social and Cross-Cultural Perspectives]. Obŝestvennye nauki i sovremennost', 3, 179-191.

Mitina, O.V., \& Petrenko, V.F. (2000). Kross-kul'turnoe issledovanie stereotipov ženskogo povedeniâ (v Rossii i SŠA) [Cross-Cultural Study of Stereotypes of Female Behavior (in Russia and USA)]. Voprosy psihologii, 1, 68-86.

Mitina, O.V., Cuthbert, A., \& Nizovskikh, N.A. (2003). Ideologiâ maskulinnosti v Rossii: postanovka problemy i èksperimental'noe issledovanie [Ideology of Masculinity in Russia: The Issues and Experimental Study]. Obsestvennye nauki i sovremennost', 2, 164-176.

Nieva, V., \& Gutek, B. (1981). Women and Work. New York: Praeger.

Olson, J., Frieze, I., Wall, S., Zdaniuk, B., Telpuchovskaya, N., Ferligoj, A., Kogovљek, T., Horvat, J., 乃arlija, N., Jaroљová, E., Pauknerová, D., Luu, L., Kovacs, M., Miluska, J., Orgocka, A., Erokhina, L., Mitina, O., Popova, L., Petkevichiute, N., Pejic Bach, M., \& Rus Makovec, M. (2006). Economic Influences on Ideals About Future Jobs in Young Adults in Formerly Socialist Countries and the United States. Cross-Cultural Research, 40 (4), 352-376.

Petrenko, V.F. (1987). Psihosemantičeskij podhod k ètnopsihologičeskim issledovaniâm [Psychosemantic Approach to Ethnopsychological Studies]. Sovetskaâ ètnografiâ, 3, 22-38.

Petrenko, V.F. (2005). Osnovy psihosemantiki [Principles of Psychosemantics] (2nd ed.). Saint Petersburg: Piter.

Petrenko, V.F., \& Mitina, O.V. (2008). Using Psychosemantic Methods in Political Psychology. In Yu.P. Zinchenko \& V.F. Petrenko (Eds.), Psychology in Russia: State of the Art. Scientific Yearbook. Moscow: MSU. 
Schetilina, E.S. (2006). Gendernye stereotipy sovremennoj rossijskoj studenčeskoj molodëži [Gender Stereotypes of Contemporary College and Universities Students in Russia]. http://www.cs-alternativa.ru/text/2379

Shlapentokh, D. (1992). Lovemaking in the Time of Perestroika: Sex in the Context of Political Culture. Studies in Comparative Communism, XXV (2), 151-176.

Spence, J.T., \& Hahn, E.D. (1997). The Attitudes toward Women Scale and Attitude Change in College Students. Psychology of Women Quarterly, 21, 17-34.

Stolin, V.V. (1979). Kognitivno-motivacionnaâ struktura ličnosti i otnošenie k drugim lûdâm [Cognitional and Motivational Structure of Personality and Attitudes towards Others]. In Vzaimodejstvie kollektiva i ličnosti v kommunističeskom vospitanii. Tallinn.

Stolin, V.V. (1983). Samosoznanie ličnosti [Self-Consciousness of a Person]. Moscow: MGU.

Tabachnick, B.G., \& Fidell, L.S. (2002). Using Multivariate Statistics (4th ed.). New York: HarperCollins College Publisher.

Velichkovsky, B.M., Blinnikova, I.V., \& Lapin, E.A. (1986). Predstavlenie real'nogo i voobražaemogo prostranstva [Representation of Real and Imaging Space]. Voprosy psihologii, 3, 103-112.

Voronina, O.A. (Ed.). (2001). Teoriâ i metodologiâ gendernyh issledovanij: Kurs lekcij [Theory and Methodology of Gender Studies. Lectures]. Moscow: MCGIMVŠSĖN-MFF.

Williams, J.H. (1987). Psychology of Women. Behavior in a biosocial context (3d ed.). New York: Norton. 